ارزيابى راههاى حل تعارض رودخانهُ زايندهرود از ديدگاه كشاورزان و ذىمدخلان

\author{
على يوسفى"، اميرمظفر امينى، اميد فتحى، آمنه يادكارى'
}

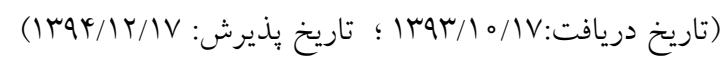

جكيده

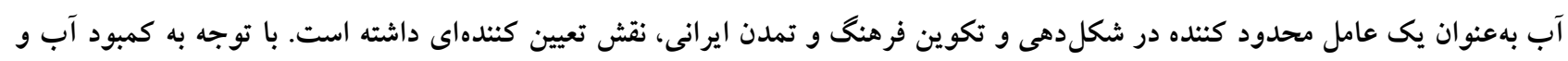

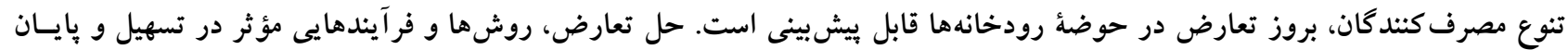

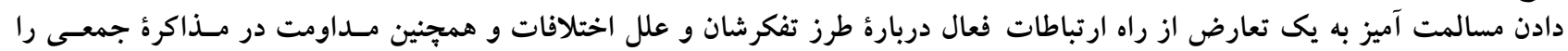

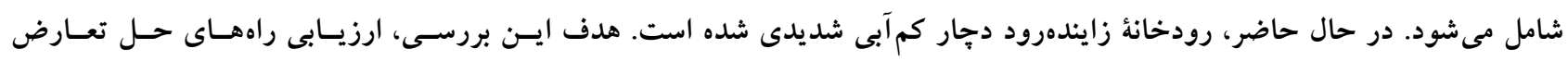

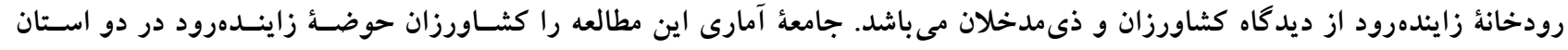

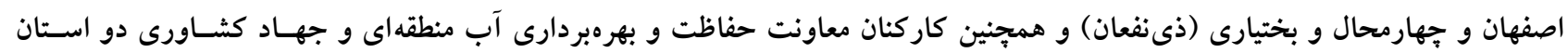

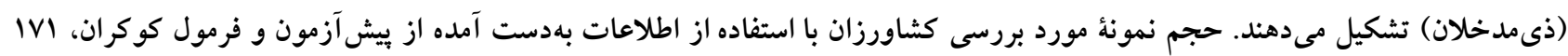

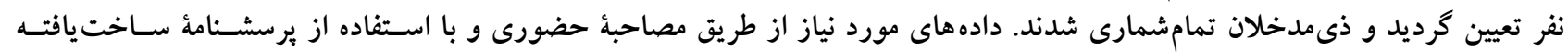

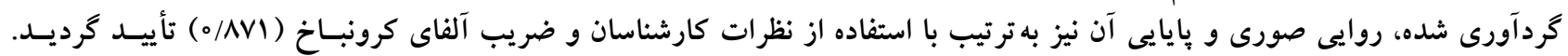

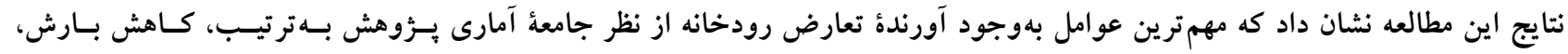

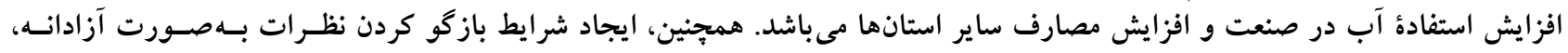

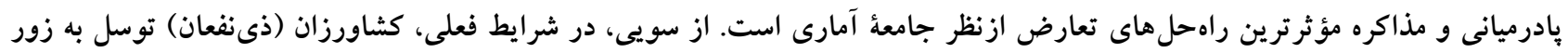

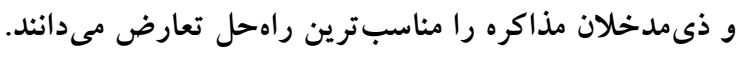

وازههاى كليدى: حل تعارض، مذاكره، توسل به زور، پادرميانى، رودخانهُ زايندهرود 
تفصيل بيان كرديده است كه در حال حاضر نيز مورد قبول عامهٔ

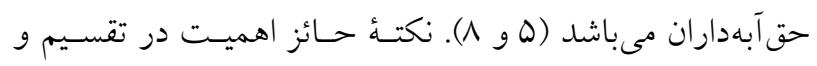
توزيع آب رودخانه در كذر زمان، مشاركت سازمان يافتسهُ مـردم

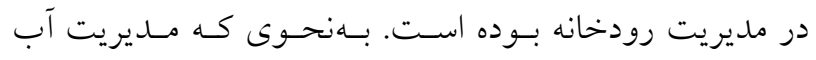

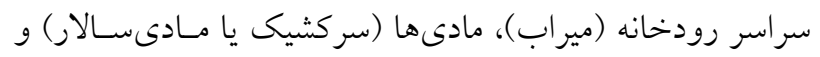

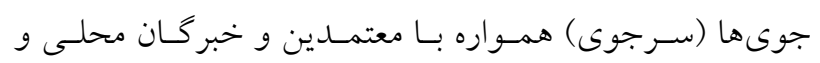

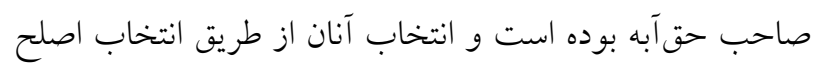

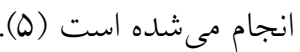

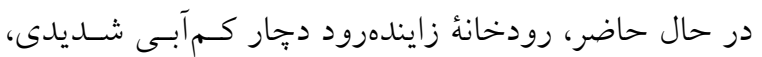
بهويزه در يايين دست آن، شده كه مشكلات اقتصادى، اجتماعى رله و زيستمحيطى فراوانى نظيـر بيكـارى كشـاورزان و مهاجرت

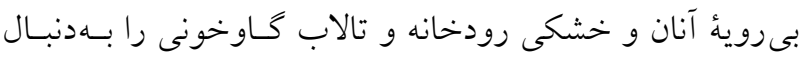

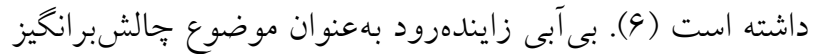
براى مردم اصفهان و ويايين دست رودخانـه تبـــيل شـــه اسـت.

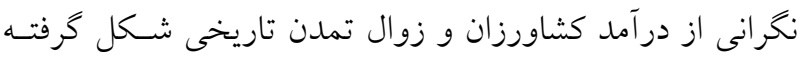
در كنار زايندهرود بر اين حوضه سايه افكنده اسـت ( ا و \&). از

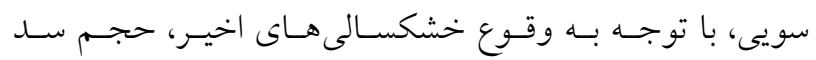

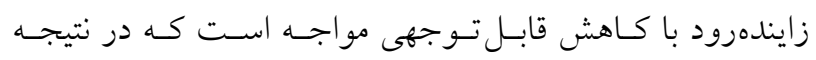

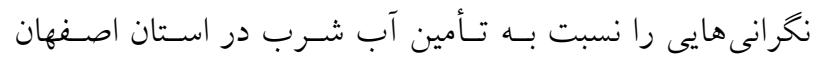

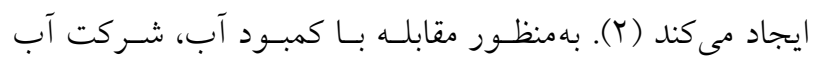

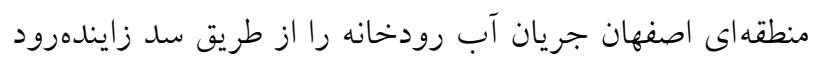

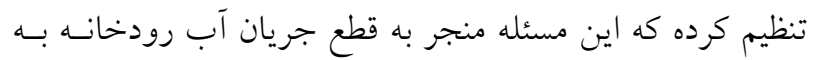

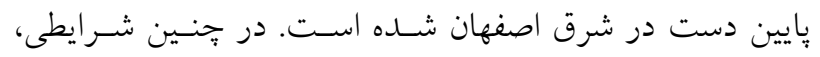

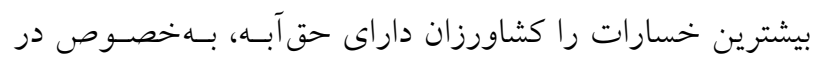

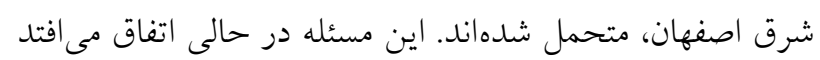

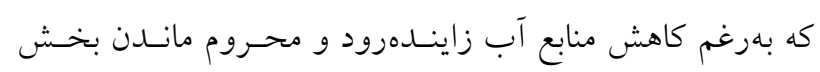

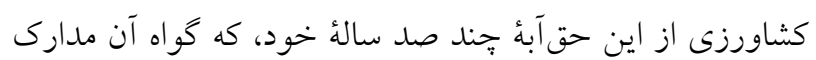

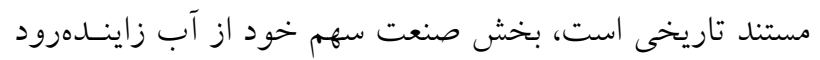

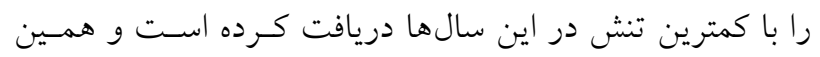
موضوع سـبب اعتــ اض بسـيارى از كشـاورزان شـــه اسـت. از

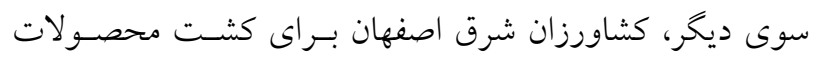

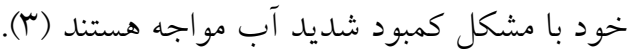

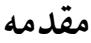

توانايى انسان در مهار و بهرهبردارى منابع آب بـهمنظـور تـأمين

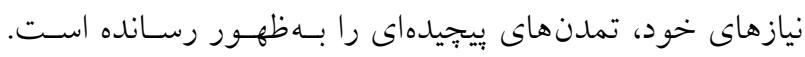

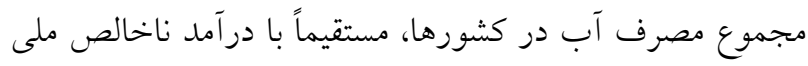

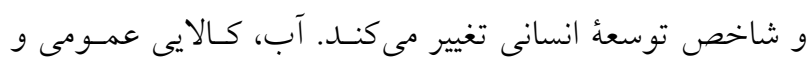

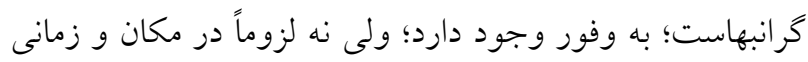

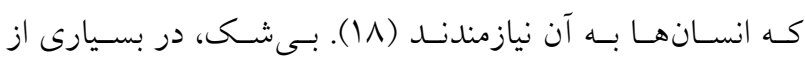

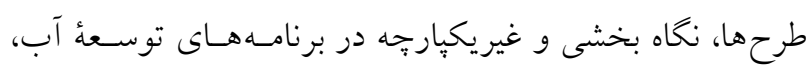

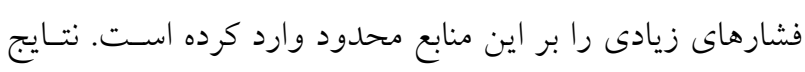

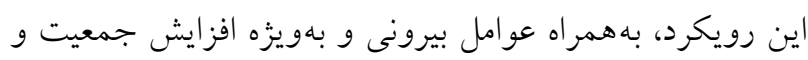

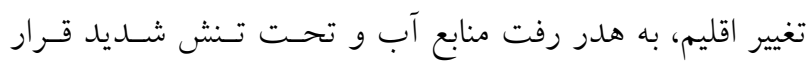

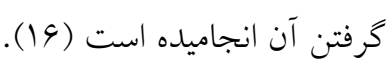

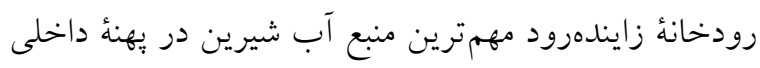

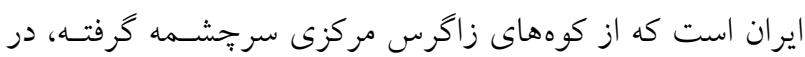

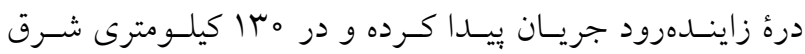
اصفهان به باتلاق كاوخونى مىريزد. ساكنان اين منطقه از ديرباز

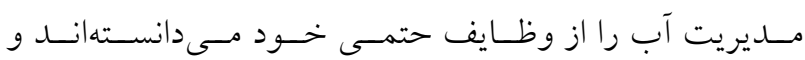

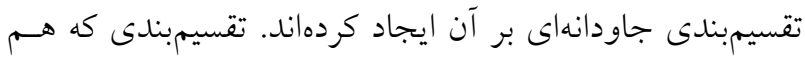

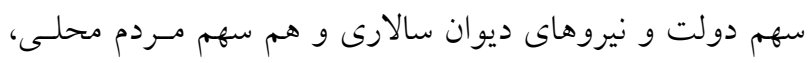

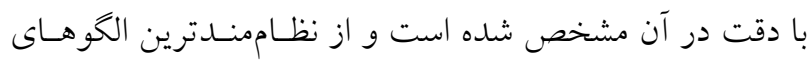

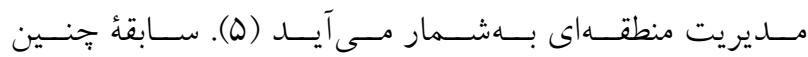
تقسيمبندىهايى به عمر و سابقهُ حضور انسان در جلكةٔ اصفهان باز مى گردد. بهعبارتى، از زمانى كه جمعيت اسكاني يافته در ايسن

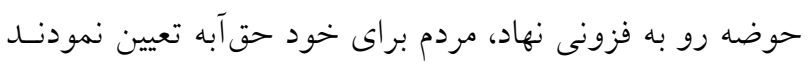

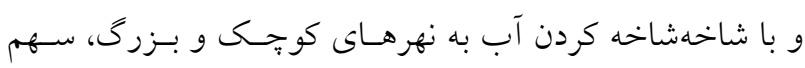

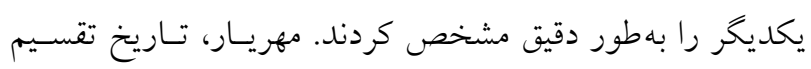

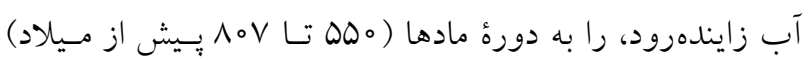

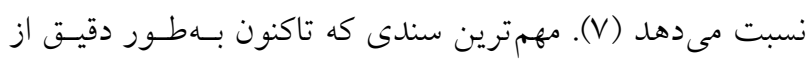

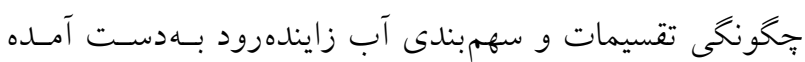

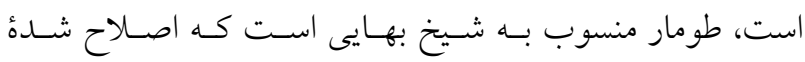

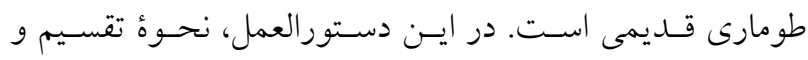
توزيع آب رودخانه بين بخش هاى مختلف اراضى حق آبهدار بـهـ 
آن، از تنشهاى بنهان تا خشونت آشكار مشاهده كرد. از اينـرو،

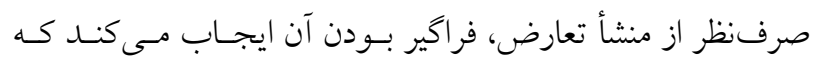

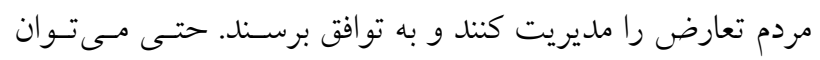

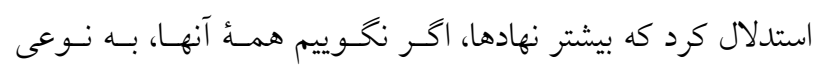

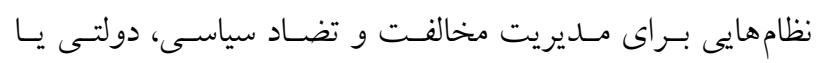
قضايى هستند.

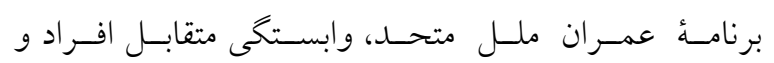

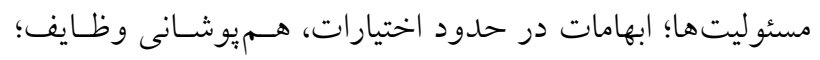

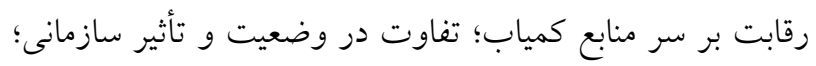

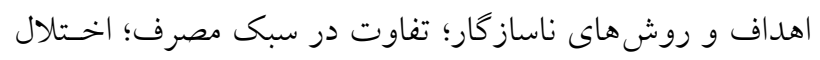

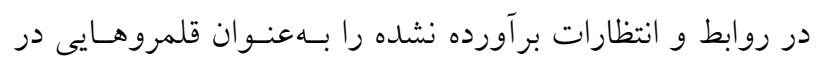

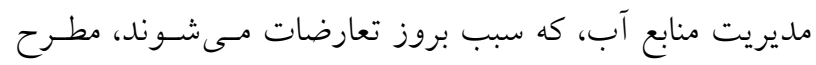

مى كند (10) (10)

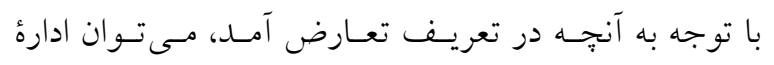

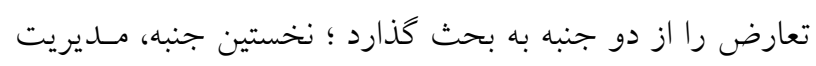

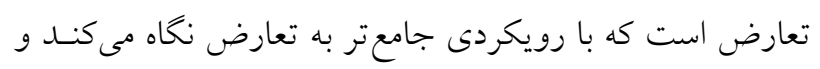

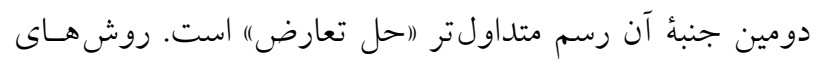

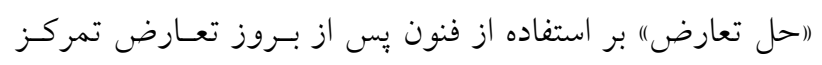

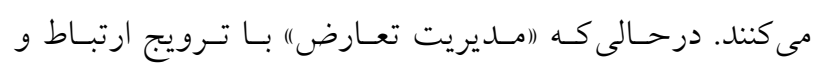

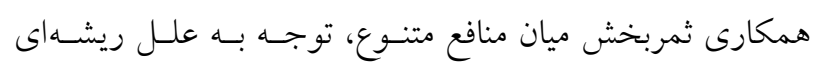

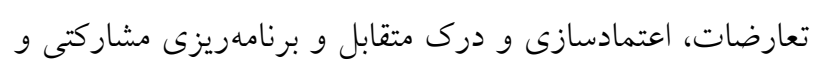

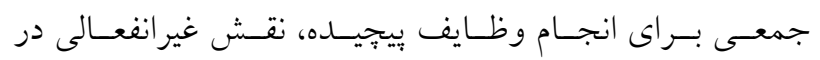
جلو گيرى از تعارض ايفا مى كند (r) (IT).

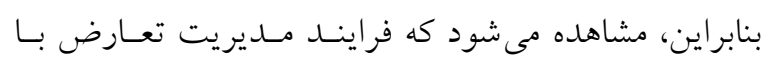

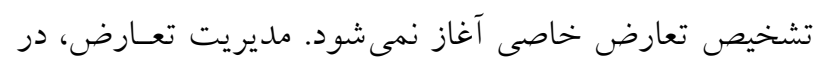

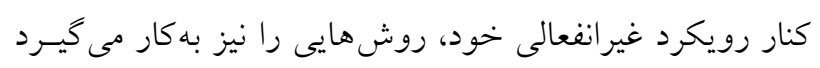

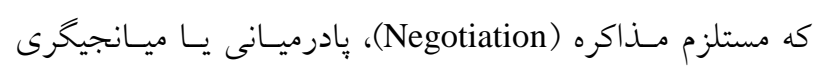

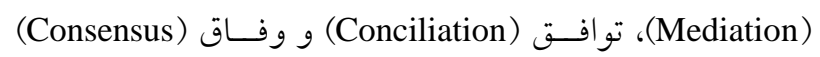

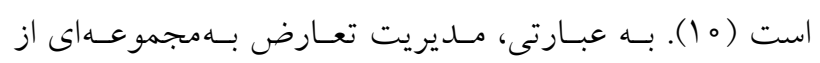

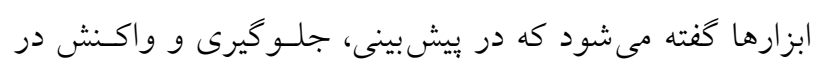

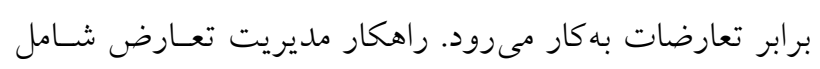

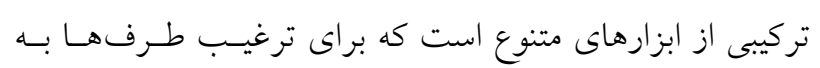

بهوطور كلى و بهعنوان يك اصل بايد بيذيريم كه تمامى انواع

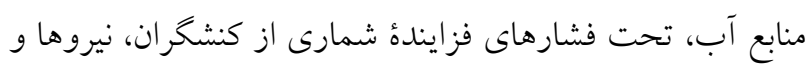

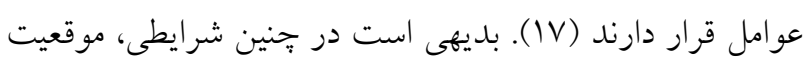

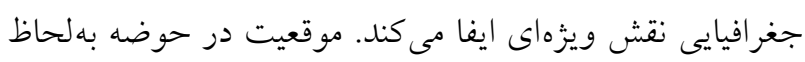

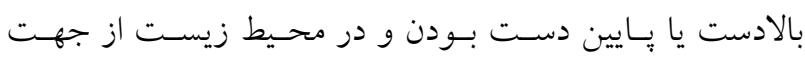

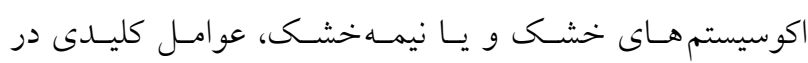

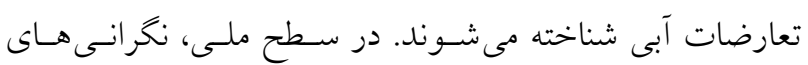

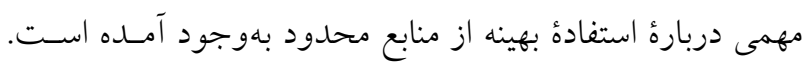
بحث ها و اختلافات ميـان طيـف وسـيعى از مصـرف كنتـدكان،

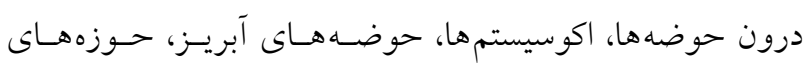

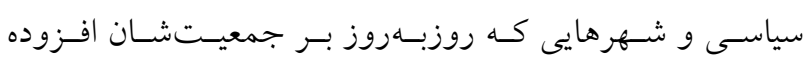
مىشود، در حال ظهور است (19).

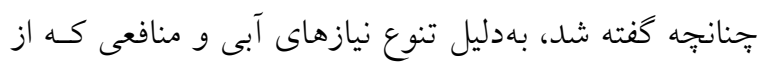

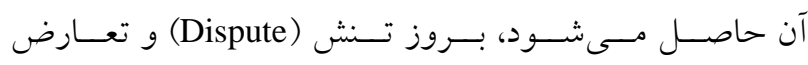

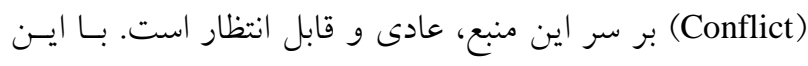

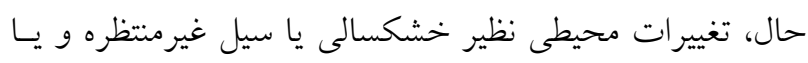

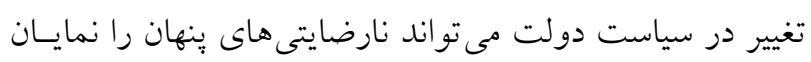

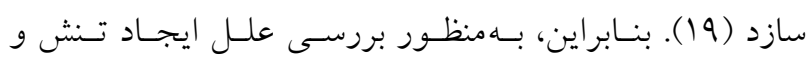

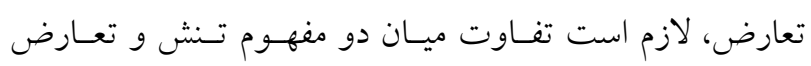

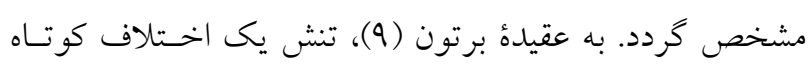

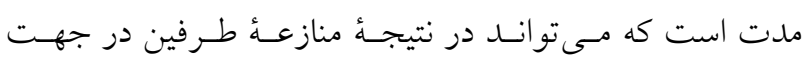

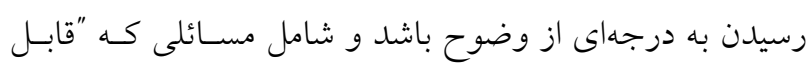

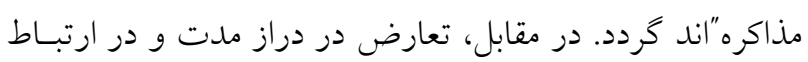

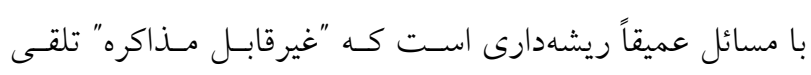

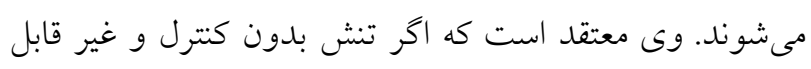

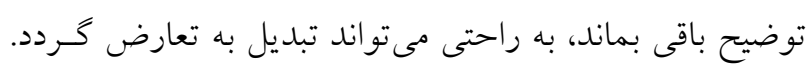

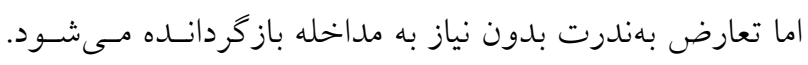

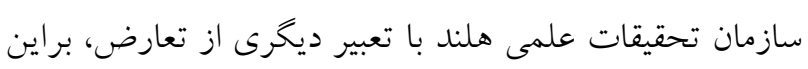

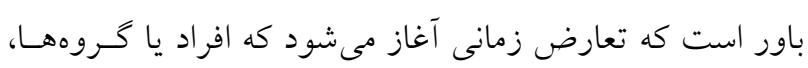

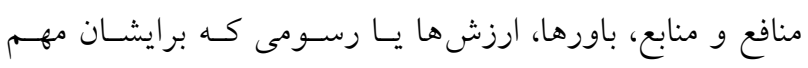

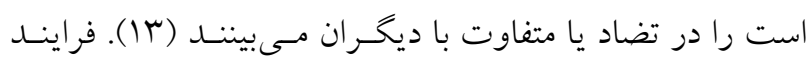

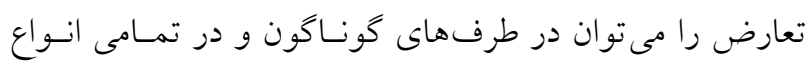


تنها راه براى حل تعارض است. ولسى در مـوارد ديخـر، ممكـن

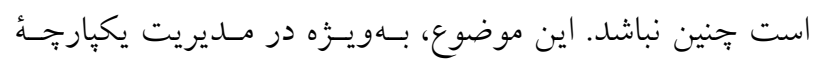

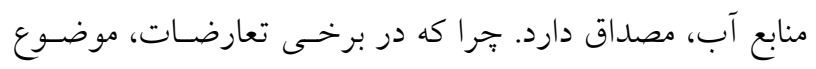

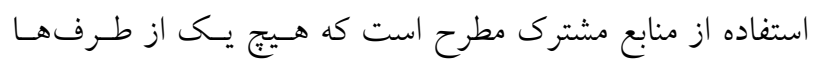

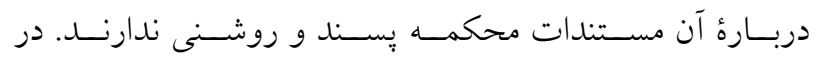

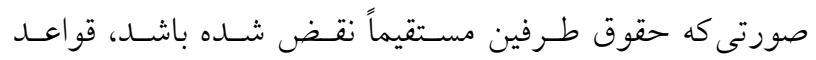

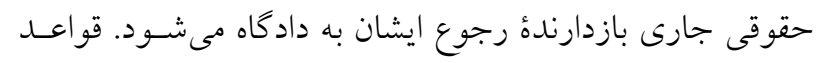
حقوقى جارى ممكن است مانع دسترسى شـاكى بـه دادكَاهــا

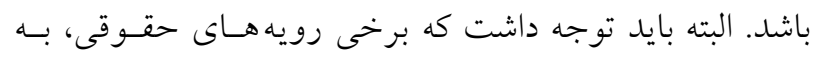

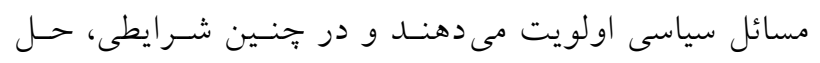

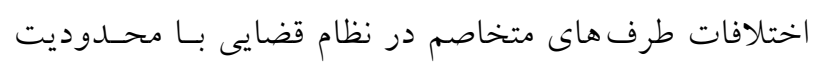

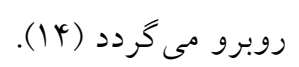

بدين سان، حل اختلافات يا تعارضات با نتايج حقوقى همراه

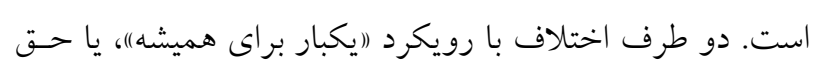

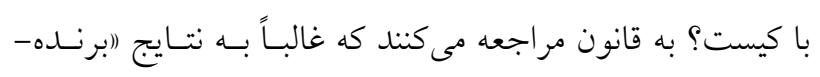

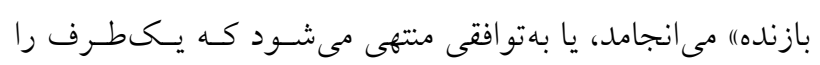

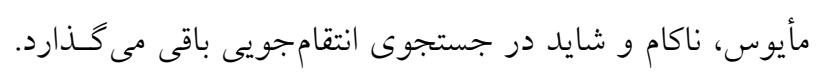

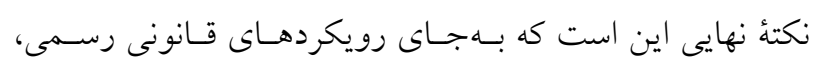
كزينسهــاى حسل اخستلاف ( Alternative dispute resolution

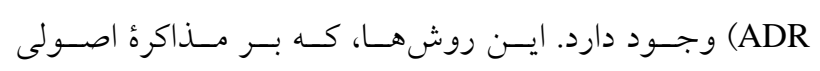
مبتنى هسـتند، بـا تمايـل جــــ (Principled negotiation)

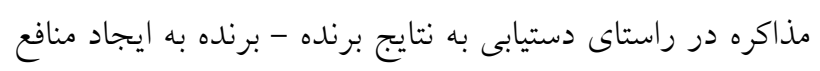
درازمدت منجر مى گردند (11) در اين نوشتار كه حاصل يك يُزوهش ميدانى است، تـلاش

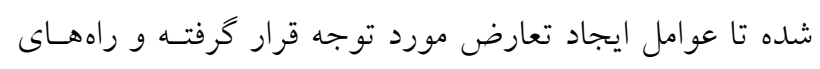

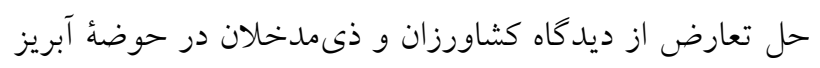
رودخانه زايندهرود شناسايى شود.

\section{مواد و روشها}

جامعهُ آمـارى مطالعـه را كشـاورزان حوضـهُ زاينـدهرود در دو

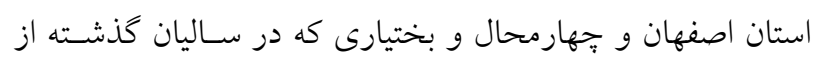
آب رودخانه استفاده كردهاند، يا در حال حاضر استفاده مى كنتـد
شناسايى مسائل واقعى يشت سر مواضع اعـلام شــده و يـافتن

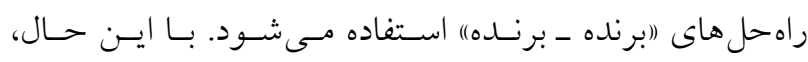

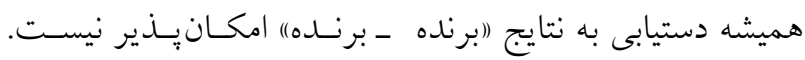

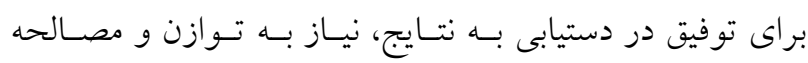

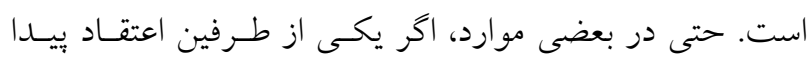

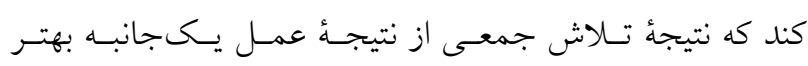

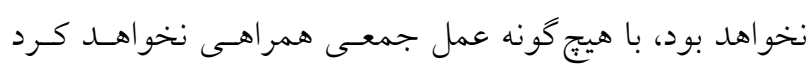

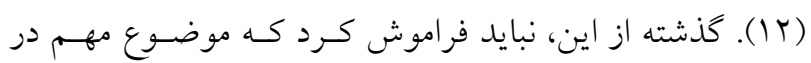

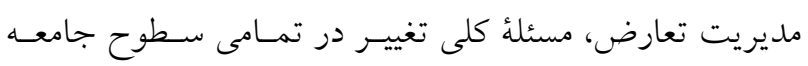

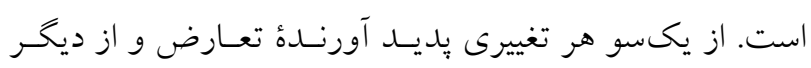

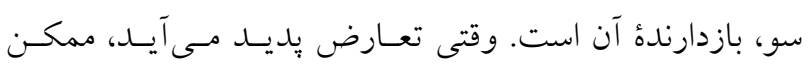

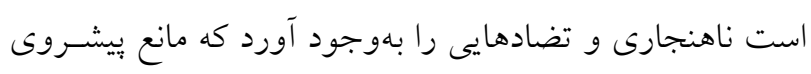

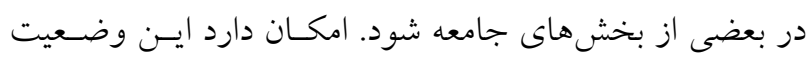

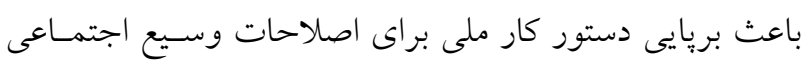

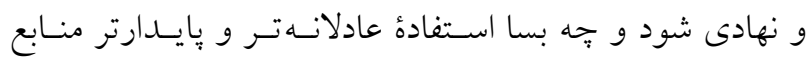

طبيعى را نتيجه دهد (11). در مورد دومين جنبه از اداره تعارض (حل تعـارض)، بايسـ

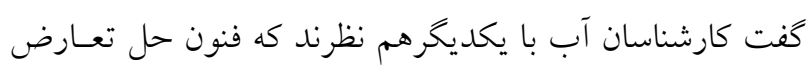

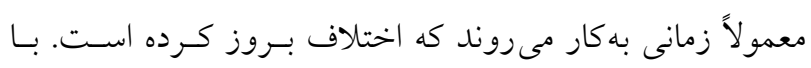

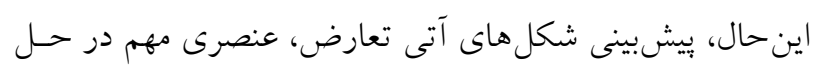

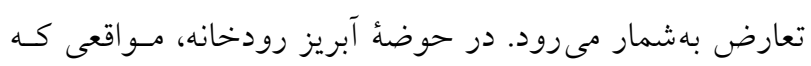

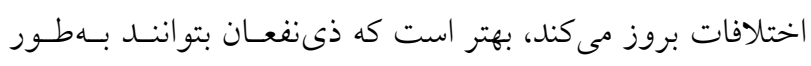

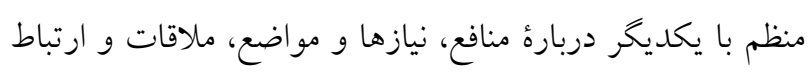

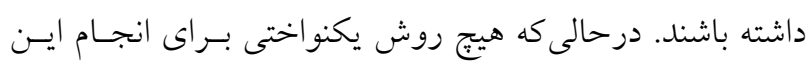

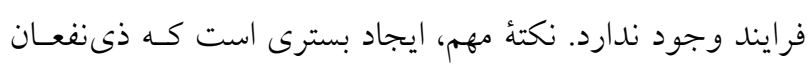

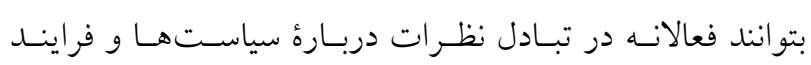
برنامهريزى و طراحى بعد از آن مشاركت كنند (T) (I).

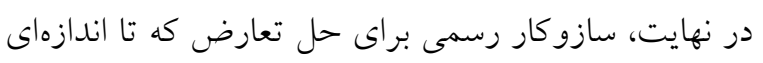

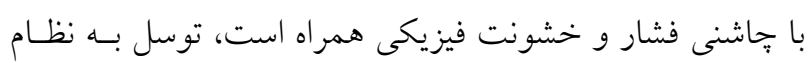

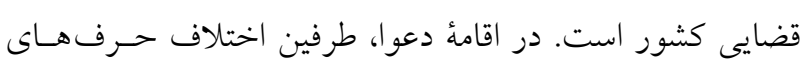

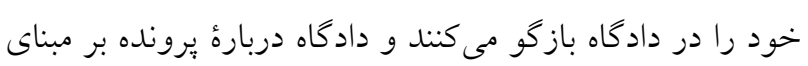

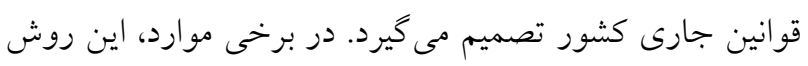


جدول ا. ويزُگیىهاى بِاسخگويان مورد مطالعه

\begin{tabular}{|c|c|c|c|}
\hline مرصد & 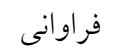 & & 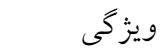 \\
\hline $9 / 4$ & 10 & جهاد كشاورزى استان اصفهان & \\
\hline$V / 9$ & 19 & آب منطقهاى استان اصفهان & \\
\hline $9 / \pi$ & 10 & جهاد كشاورزى استان جهارمحال و بختيارى & ذىمدخل \\
\hline$V / 9$ & 19 & آب منطقهاى استان جهارمحال و بختيارى & \\
\hline$r \Lambda / 4$ & $9 \wedge$ & جمـع & \\
\hline$V / 0$ & 11 & روستاهاى استان جهارمحال و بختيارى & \\
\hline $11 / \mathrm{V}$ & rA & روستاهاى بالادست استان اصفهان (كانالهاى سنتى) & \\
\hline $10 / 9$ & rᄉ & روستاهاى شبكة نكو آباد & \\
\hline $11 / \mathrm{V}$ & rᄉ & روستاهاى شبكة آبشار و برخوار & 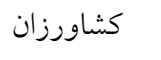 \\
\hline $\mid r / 1$ & rq & روستاهاى شبكة مهيار & \\
\hline $1 r / 9$ & r。 & روستاهاى شبكأ رودشتين & \\
\hline$V Y / D$ & $|V|$ & جمـع & \\
\hline
\end{tabular}

نشان مى دهد.

بـهنظـور تصـحيح يرسشـنامه، انــازهذيـرى ميـزان آلفــاى كرونباخ و تعيين حجم نمونه، نخسـت تعـداد مبإيرسشـنامه در هر دو بخش بالادست و يايين دست حوضه توزيع شد. يُس از اعمال اصلاحات مورد نياز، برسشنامهٔ مقدماتى مورد تأييد قـرار كرفت. براى تعيين اعتبار ابزار انسدازهيـرى روشهــاى متعـددى وجـود دارد. اعتبار محتوا، ويزگى ساختارى ابزار اسـت كـهـ همزمـان بـا تدوين آزمون در آن تنيده مى شود. اعتبار محتواى آزمـون توسط آنسط

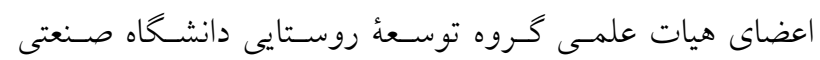
اصغهان مورد تأييد قرار كرفت. اعتبار عاملى نيـز از طريـق روش تحليـل عـاملى و محاسـبهُ آمـاره (Kaiser-Meyer-Olkin) KMO انجام شد كه نتايج آن در جدول (Y) نشان از مناسب بودن دادهها جهت استفاده در تحليل عاملى دارد.

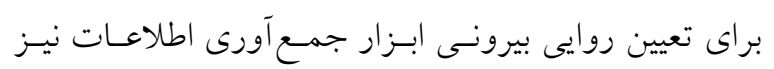

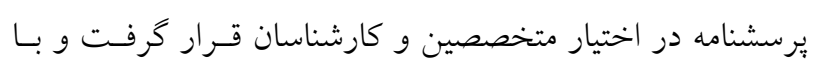

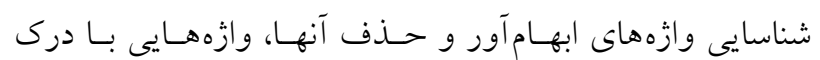
مشابه جايخزين كرديد و به يكسانسازى مفهومى وازههـا اقـدام
(ذى نفعان)، و همحِنين كاركنان معاونت حفاظت و بهرهبــردارى آب منطقهاى و دفتر آب و خاى جهاد كشاورزى (ذىمـدخلان)

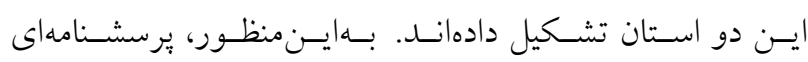
يزوهشخر ساخته، با يرسش هـايى در قالـب طيـف ليكـرت، در

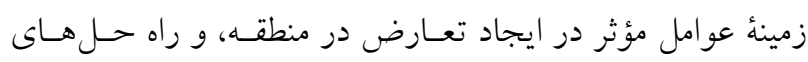
آنها، طراحى و تدوين شد. روند

روش تحقيق در اين بررسى مبتنى بر بر شـيوه بيمايشسى و

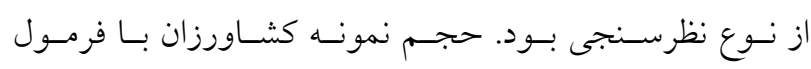
كوكران اVI نفر تعيين شد و دادههاى مورد نياز بـا اسـتفاده از

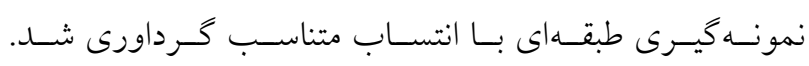
بدين ترتيب كه نخست روستاهاى مورد مطالعهُ منطقهُ يـرزوهش

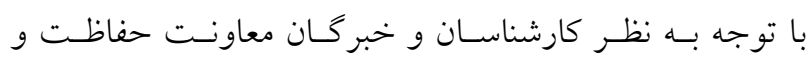
بهرهبردارى آب منطقهاى، بـه سـه بخـش تقسـيم شـد: قسـمت بالادسـت در اسـتان جهارمحســال و بختيــارى و دو قسـمت فئ بالادست و يايين دست در استان اصـفهان. سـيس، نمونسهُ هـر بخش براساس سهم جمعيت از كـل تعيسين كرديــ. هم:جنسين، ذىمدخلان در دو استان سرشمارى شــند. جــدول (1)، سـهم كشاورزان و ذىمدخلان از كـل ياسـخحويان مـورد مطالعـه را 
نشريه علوم آب و خاك (علوم و فنون كشاورزى و منابع طبيعى) / سال بيستم / شماره هفتاد و ششم/ تابستان هوس|

جدولr. آزمون اعتبار سازههاى تشكيل دهنده مربوط به كل باسخگويان

\begin{tabular}{|c|c|c|c|}
\hline Sig & آزمون بارتلت & آزمون KMO & 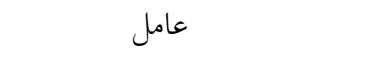 \\
\hline$\circ \%$ & $r q V Y / D$ &.$/ 9 \wedge 9$ & رقابت بر سر منابع كمياب \\
\hline$\circ / \circ \circ$ & $19 V Q / \Gamma \mid$ & $\circ / N H_{0}$ & اهداف و روش هاى ناساز كار \\
\hline$\circ / 0 \circ$ & $19 \pi / T$ & ०/VTQ & حدود اختيارات حال \\
\hline$\%$ & lQVV/4。 & $0 / 994$ & حدود اختيارات آينده \\
\hline$\circ / \circ \circ$ & rY9Q/10 & $\circ / N T q$ & راههاى كنونى حل تعارض \\
\hline$\circ \%$ & $1094 / Y Y q$ &.$/ 910$ & راههاى ييشنهادى حل تعارض \\
\hline
\end{tabular}

جدولr. اندازهيرى ميزان آلفاى كرونباخ براى هر حيطهُ مربوط به كل باسخگويان

\begin{tabular}{|c|c|c|}
\hline ت تعداد متغير & ميزان آلفاى كرونباخ & 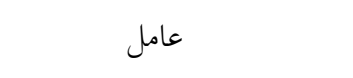 \\
\hline ir &.$/ 94$ & رقابت بر سر منابع كمياب \\
\hline 9 & - /NQF & اهداف و روشهاى ناساز كار \\
\hline$\wedge$ & $\circ / N 11$ & حدود اختيارات حال \\
\hline$\wedge$ & $0 / 994$ & حدود اختيارات آينده \\
\hline$\checkmark$ & $\circ / N T a$ & راههاى كنونى حل تعارض \\
\hline v &.$/ 9 \wedge \Delta$ & راههاى يبشنهادى حل تعارض \\
\hline
\end{tabular}

تشديد جنين تنشهايى در سالهاى آينده، بـهـ تعيسين متغيرهـاى

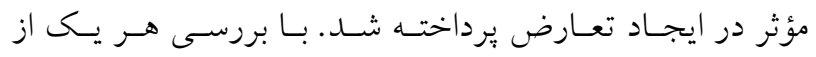

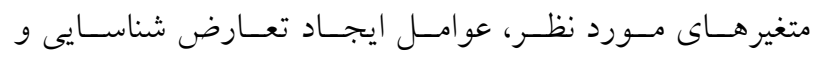
راهحل هاى تعارض براى منطقة مورد مطالعه تبيين گرديد.

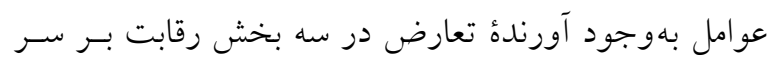

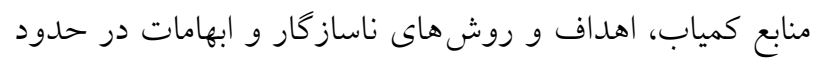

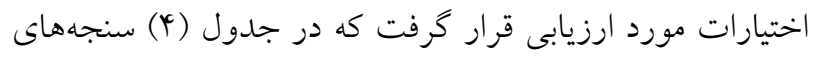

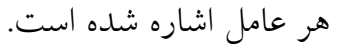

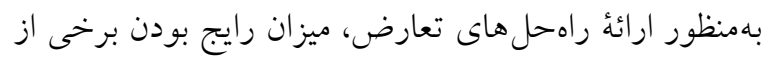

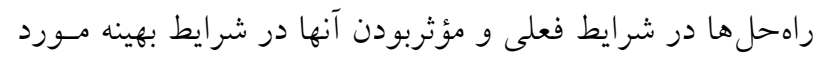

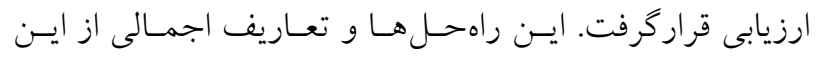
فنون، در جدول (ه) ارائه شده است.
شد. براى سنجش روايى درونى نيز حضور تمـامى متغيرهـا

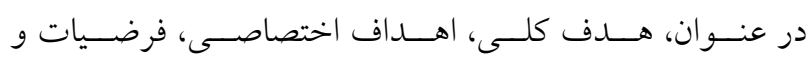

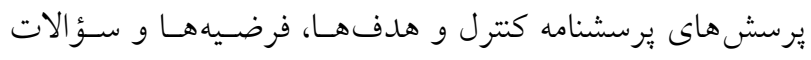

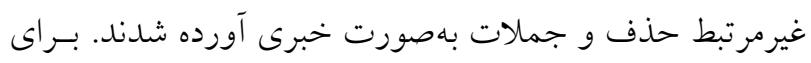

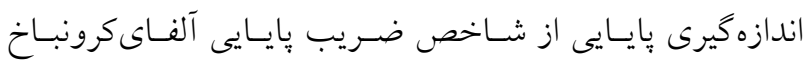

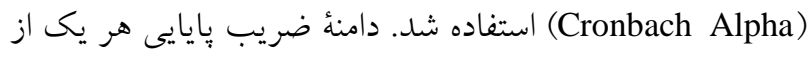
مفاهيم در جدول (r) نشان داده شده است. در تجزيه و تحليل دادها، با توجه به ويزگكىهـاى دادههـاى

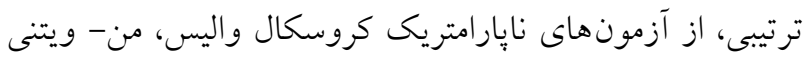
و ويلكاكسون استفاده شده است.

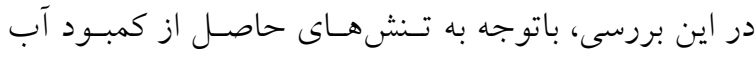

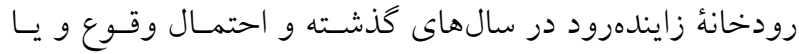


جدول †. عوامل ايجاد تعارض و سنجههاى مربوط به آن

\begin{tabular}{|c|c|c|}
\hline حدود اختيارات بخشها & اهداف و روش هاى ناساز كار & رقابت بر سر منابع كمياب \\
\hline 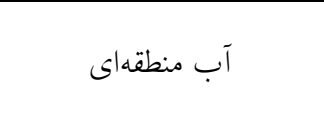 & احداث سد روى رودخانه زايندهرود و عدم تناسب آن & افزايش تعداد كشاورزان \\
\hline جهادكشاورزى & احداث خاههاى حريمى & افزايش مصرف كشاورزان \\
\hline بخش صنايع و معادن & نوع كياهان مورد استفاده در فضاى سبز شهرى و عدم & افزايش سطح زيركشت \\
\hline 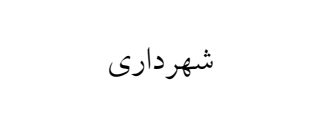 & احداث كارخانهاى مختلف در حوضئ & افزايش استفادة آب در صنعت \\
\hline نمايند كان كشاورزان منطقه & وجود تصميم گيرندگان مختلف در سراسر رودخانه & افزايش واحدهاى صنعتى استفاده كننده از آب \\
\hline شوراى خبر كان كشاورزى & اجرا نشدن قانون توزيع عادلانهُ آب به دليل & افزايش آب مصرفى در شهرها \\
\hline نظام صنفى كشاورزى & & افزايش مصارف شهر اصفهان \\
\hline \multirow[t]{6}{*}{ شركت بهرهبردارى ميراب } & & افزايش مصرف شهرهاى ديخر استان \\
\hline & & افزايش مصارف استانهاى ديخر \\
\hline & & افزايش آب مصرفى در زمينهُ \\
\hline & & فضاى سبز شهرها \\
\hline & & افزايش آب مصرفى در بخش نظامى \\
\hline & & كاهش بارش \\
\hline
\end{tabular}

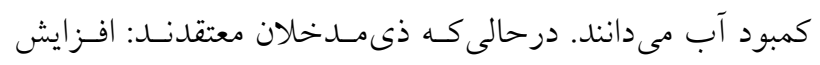

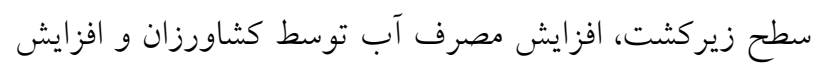

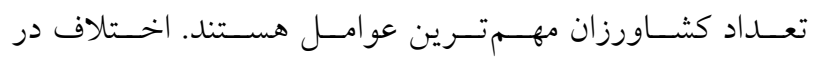

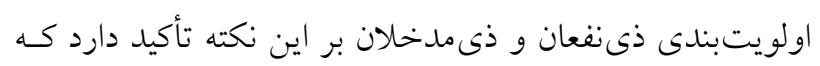
در منطقه تعارض وجود دارد.

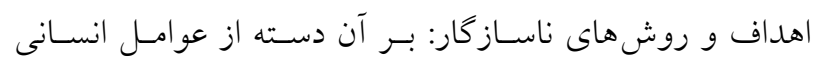

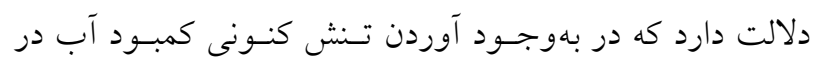

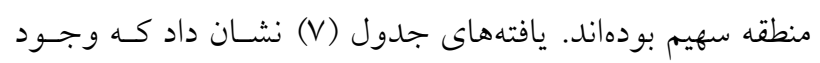

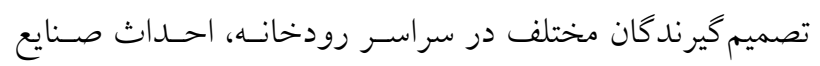

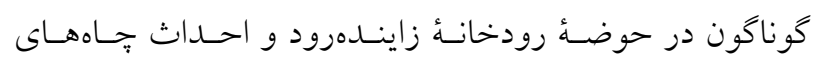

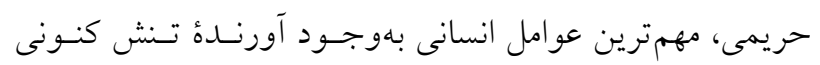

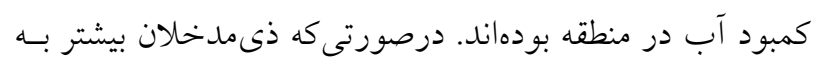

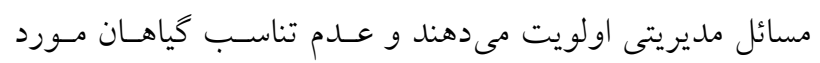

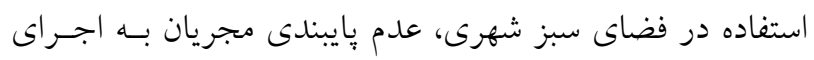

\section{نتايج و بحث}

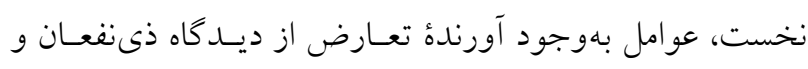

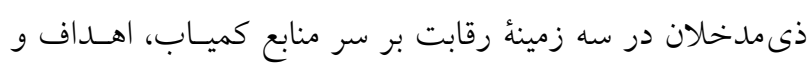

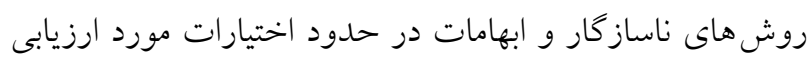
قرار مى گيرد. رقابت بر سر منابع كمياب، بر عواملى دلالت دارد كه باعـث

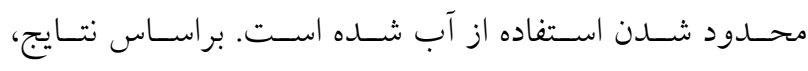

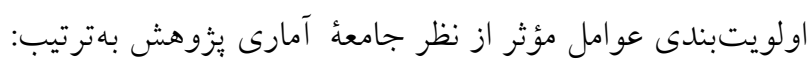

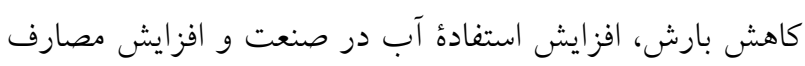

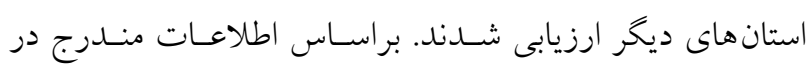

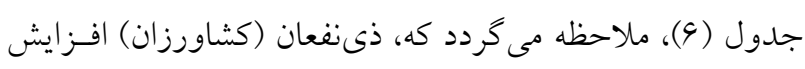

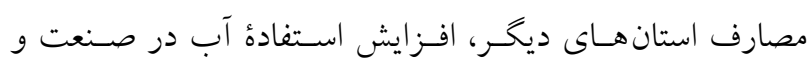

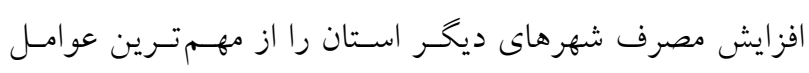


جدوله. راهحل هاى تعارض و تعاريف آنها (م (1)

\begin{tabular}{|c|c|}
\hline تعاريف & راهحل هاى تعارض \\
\hline طرفين اختلاف حرفهاى خود را در داد كاه باز گو كرده، داد كاه دربارهُ يرونده بر مبناى قوانين جارى & شكايت (اقامهُ دعوا) \\
\hline فرايندى است كه طرفين اختلاف، براى رسيدن به راهحل مرضى الطرفين به كفت و گو مىنشينند. هيج & 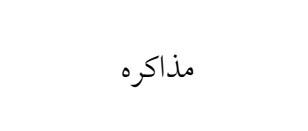 \\
\hline 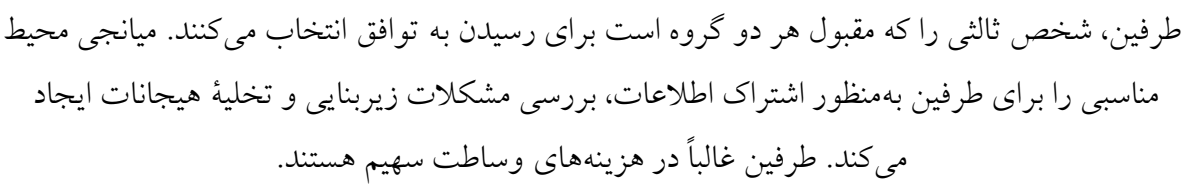 & يادرميانى (ميانجى گرى) \\
\hline حاورى غالباً در مواردى كه طرفها مهايلند راهحل هاى سريع براى مشكلات ييدا كنند به كار مىرود. داور يا & داورى (حكميت) \\
\hline زمانى كه طرفهاى درگير منافع خود را ناسازگار مى يابند، مواضع خصمانه مى گيرند يا منافع خود را از & ت ت توسل به زور \\
\hline اين فر ايند غالباً در شرايطى استفاده مىشود كه طرف ها، مسائل و ذىنفعان مختلف وجود دارد و نيز & \\
\hline مو اقعى كه مسائل وضوح تجندانى ندارند. فردى بى طرف در طراحى و هدايت جلسات براى كمك به & 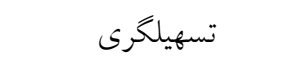 \\
\hline طرفين براى عارضهيابى، طراحى و اجراى مشترى راهحل ها شركت مى كند. & \\
\hline بركزارى جلسات عمومى، بهمنظور اينكه افراد با يكديخر صحبت و عقايد خود را مبادله نمايند. براى & ايجاد شرايط بازكو كردن \\
\hline حل موفق تعارض، تمامى طرف هاى ذينفع بايستى فرصت مشاركت در اين فرايند را داشته باشند. & نظر ات بهصورت آزادانه \\
\hline
\end{tabular}

بخش صنايع و معادن مى دانند. درحالى كه ذىمدخلان معتقدند كشاورزان داراى بيشترين سهم در تصميم گيرىها هستند. نكتـــ مهم در اين زمينه، اختلاف سليقه در نظركشاورزان (ذىنفعان) و ذيىمخحلان مي باشد. همان كونه كـه در مـرور مطالعـات نيـز

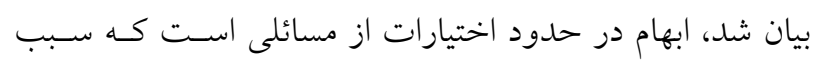
بروز تعارض مى كردد. ارزيابى نتايج حدود اختيارات تصميم گيرنـدگان در شـرايط

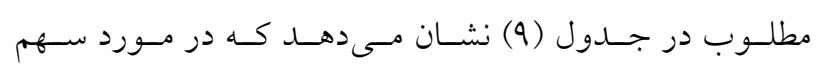
بخش هاى تصميم كيرنـده در اسـتفاده از آب (سـهمى كـه بايــد

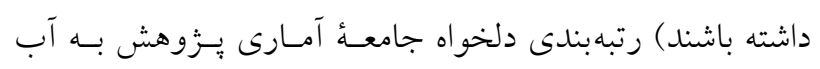

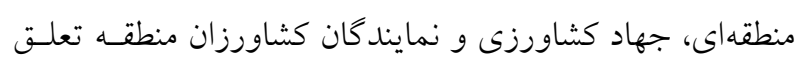

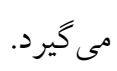

قـانون توزيـع عادلانـهُ آب و عـدم تناسـب احسـاث ســ روى رودخانه با شرايط منطقه را از مهم تـرين عوامـل انسـانى ايجـاد تنش مى دانند. جهت ارزيابى ابهامات حدود و اختيارت تصميم گيرندگان، ديدكاه جامعة آمارى در مورد سهم بخشهـاى تصـميم كيرنـده

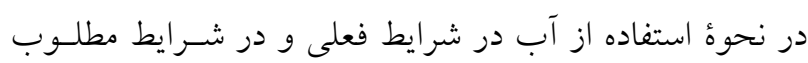
مورد سنجش قرار كرفتـه اسـت. براسـاس نتـايج جـدول (N)،

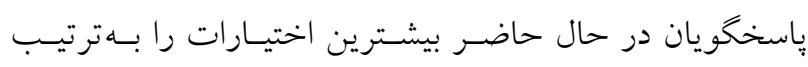
متعلق به: آب منطقـهاى، جهـاد كشـاورزى و بخـش صـنايع و معادن مى داند. بهطـورى كـه از يافتـهـهـاى جــدول برمسى آيـد،

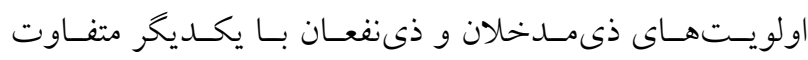
مىباشد. در توضيح بايسـ كفـت كشـاورزان در شـرايط فعلى بيشترين سهم را متعلق بـه جهـاد كشـاورزى، آب منطقـهاى و 
جدول و. اولويتبندى عوامل محدود كنندة استفاده از آب

\begin{tabular}{|c|c|c|c|c|c|c|}
\hline \multicolumn{2}{|c|}{ ذيىنفعان } & \multicolumn{2}{|c|}{ ذيىمدخلان } & \multicolumn{2}{|c|}{ كل پياسخگويان } & \multirow{2}{*}{ عو امل } \\
\hline 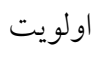 & ميانگين & 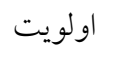 & ميانخين & 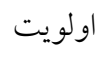 & ميانخين & \\
\hline V & $I Y Y / Y O$ & 0 & $109 / \pi \circ$ & 1 & $r|| 1 / 4 \mid$ & كاهش بارش \\
\hline r & $1 \pi / \circ 9$ & 10 & $\Lambda Y / \Lambda \Lambda$ & r & $1 \wedge \Delta Y / \Delta \circ$ & افزايش استفاده آب در صنعت \\
\hline 1 & $\mid r G / T V$ & ir & $\vee q / \circ \wedge$ & r & $\mid \Lambda F / T$ & افزايش مصارف استانهاى ديخر \\
\hline 0 & $\mid Y N / 9 V$ & $\wedge$ & $90 / \mu \mathrm{T}$ & $r$ & $|\wedge r| / T q$ & افزايش آب مصرفى در شهرها \\
\hline r & $1 r q / r 4$ & v & $99 / 49$ & $\Delta$ & $11101 / 4 q$ & افزايش مصارف شهر اصفهان \\
\hline r & $\mid r T / \wedge q$ & 9 & $\Lambda \Delta / \mu Y$ & 9 & $\mid V A Y / D Y$ & افزايش مصرف شهرهاى ديخر استان \\
\hline 9 & $\mid r V / 90$ & 4 & $99 / 01$ & v & $\mid V T Y / T$ & افزايش واحدهاى صنعتى استفاده كننده از آب \\
\hline$\wedge$ & $110 / 99$ & $r$ & $11 \% / 0 \mathrm{~V}$ & $\wedge$ & $1 T T Q / 99$ & افزايش آبمصرفى در زمينهُ فضاى سبز شهرها \\
\hline ir & $V Y / \Delta r$ & 11 & $\Lambda \circ / 44$ & 9 & $\Lambda \circ Y / \circ \Delta$ & افزايش آب مصرفى در بخش نظامى \\
\hline $1 \circ$ & $9 \mu / r \wedge$ & r & $1 \wedge \mathrm{V} / 19$ & $1 \circ$ & $\mathrm{V} / \mathrm{V} / 19$ & افزايش مصرف كشاورزان \\
\hline 11 & $q \circ / 4 y$ & 1 & $194 / \mu r$ & 11 & $V \circ Y / V V$ & افزايش سطح زيركشت \\
\hline 9 & $91 / 44$ & r & $\mid V T / 10$ & ir & $99 V / 90$ & افزايش تعداد كشاورز \\
\hline
\end{tabular}

جدولV. اولويتبندى عوامل انسانى بهوجود آورنده كمبود آب در منطقه

\begin{tabular}{|c|c|c|c|c|c|c|}
\hline \multicolumn{2}{|c|}{ ذئفعان } & \multicolumn{2}{|c|}{ ذيىمدخلان } & \multicolumn{2}{|c|}{ كل پِاسخگويان } & \multirow[t]{2}{*}{ 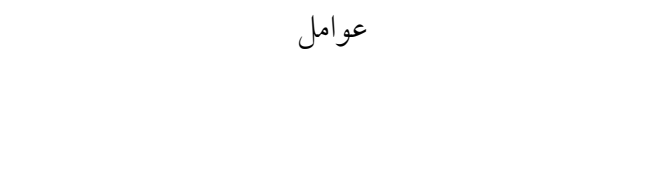 } \\
\hline 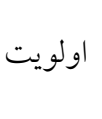 & ميانخين & 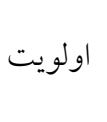 & ميانخين & 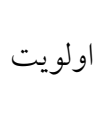 & 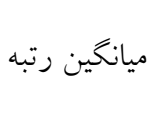 & \\
\hline r & $119 / \circ 4$ & 1 & $94 / 44$ & 1 & $9 \circ 9 / \circ 4$ & وجود تصميم گيرند گان مختلف در سراسر رودخانه \\
\hline 1 & IrT/AV & r & $100 / \mathrm{V} \circ$ & r & $\Lambda \Delta V / \circ \mathcal{F}$ & احداث كارخانههاى مختلف در حوضة رودخانهُ \\
\hline r & $1 Y Y / 07$ & $\Delta$ & $90 / 01$ & r & $\Lambda \mu \mathrm{rqq}$ & احداث جاههاى حريمى \\
\hline 7 & $101 / V \pi$ & r & $\mid \circ \Delta / 71$ & r & $7 \Delta \Delta / \Delta V$ & اجرا نشدن قانون توزيع عادلانهُ آب بهدليل عدم يايبندى \\
\hline r & $1 Y \circ / 9 V$ & $r$ & $1 \circ Y / \Psi \Lambda$ & $\Delta$ & $\Delta N^{E} N / V Y^{k}$ & احداث سد روى رودخانهُ زايندهرود و عدمتناسب آن با \\
\hline$\Delta$ & I0T/Kr & 1 & ITV/TV & 7 & raN/IT & نوع گياهان مورد استفاده در فضاى سبز شهرى و عدم \\
\hline
\end{tabular}

مقدار Z آزمـون و سـطح معنسى دارى در جـدول (ه أرئسه كرديله است. سطح معنى دارى كمتـر از هـ/ بيـانخر اخـتلاف نظر هر كروه در خصوص شـرايط فعلى و مطلـوب مسىباشـد.
به منظور مقايسهُ ديد گاه اعضاى جامعـهُ آمـارى (ذى نفعـان و

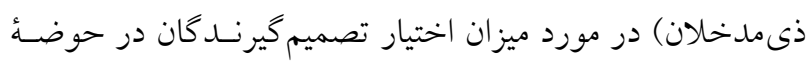
زايندهرود از آزمون ويلكاكسون استفاده كرديد. 
جدوله. اولويتبندى سهم بخشهاى تصميم گيرنده در نحوه استفاده از آب در شرايط فعلى

\begin{tabular}{|c|c|c|c|c|c|c|}
\hline \multicolumn{2}{|c|}{ ذىنفعان } & \multicolumn{2}{|c|}{ ذى ذمدخلان } & \multicolumn{2}{|c|}{ كل پاسخخُويان } & \multirow{2}{*}{ عوامل } \\
\hline 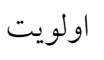 & ميانخين رتبه & 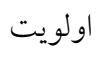 & ميانخين رتبه & 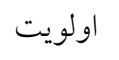 & ميانخين رتبه & \\
\hline r & $\mid r \circ / r \mu$ & 7 & $94 / V G$ & 1 & $177 \% / V Y$ & آب منطقهاى \\
\hline 1 & $\mid T Q / \circ G$ & v & $\Lambda \Delta / 1 Q$ & r & $|F \Delta| / 7 V$ & جهاد كشاورزى \\
\hline r & $9 N / 94$ & $\wedge$ & $V Y / r q$ & r & $11 / N / 0$ 。 & بخش صنايع و معادن \\
\hline$\varphi$ & $90 / \Gamma \wedge$ & 1 & $\mid K Y / 99$ & r & $\Lambda T / Y Y$ & نمايند كان كشاورزان منطقه \\
\hline$\wedge$ & $9 \% / 91$ & 0 & $119 / \pi r$ & 0 & TIT/7r & شهردارى \\
\hline 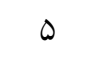 & $V 0 / 90$ & $r$ & ITO/rY & 4 & $7 k T / 94$ & شركت بهرهبردارى ميراب زايندهرود \\
\hline$\checkmark$ & $90 / 91$ & r & $\mid Y N / 10$ & $\vee$ & $7 \circ Y / \Delta D$ & شوراى خبر كان كشاورزى (خانه كشاورز) \\
\hline 7 & $V \circ / V V$ & r & $\mid r Q / T D$ & $\wedge$ & $\Delta V / / \Delta /$ & نظام صنفى كشاورزى \\
\hline
\end{tabular}

جدوله. اولويتبندى سهم بخشهاى تصميم گيرنده در نحوة استفاده از آب در شرايط مطلوب

\begin{tabular}{|c|c|c|c|c|c|c|}
\hline \multicolumn{2}{|c|}{ ذئنعان } & \multicolumn{2}{|c|}{ ذىمدخلان } & \multicolumn{2}{|c|}{ كل بِاسخحويان } & \multirow{2}{*}{ 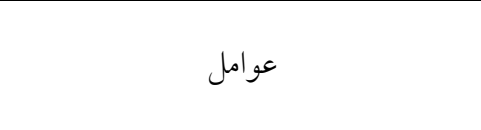 } \\
\hline اولويت & ميانگين رتبه & اولويت & ميانكين رتبه & اولويت & ميانكين رتبه & \\
\hline$r$ & $1 K 4 / 09$ & $\mathrm{v}$ & $\Lambda \Delta / 91$ & 1 & $1717 / Y 7$ & آب منطقهاى \\
\hline 1 & $\mid r V / I V$ & $\wedge$ & $\Delta V / T I$ & r & $107 \mathrm{~T} / \mathrm{VV}$ & جهاد كشاورزى \\
\hline r & $119 / 14$ & $\Delta$ & ||$r / \mu \mid$ & r & $11 r \Delta / 91$ & نمايندكان كشاورزان منطقه \\
\hline$r$ & $94 \%$ & 7 & $10 \Delta / 4 V$ & $r$ & $\Lambda Y Y / V T$ & بخش صنايع و معادن \\
\hline 0 & $\wedge 9 / 41$ & $r$ & ||$\varphi / 4 \mid$ & 0 & 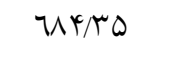 & 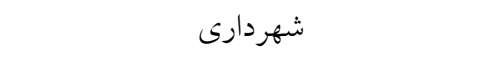 \\
\hline$\wedge$ & $\Lambda T / N T^{2}$ & r & $1 T \omega / v \Lambda$ & 9 & $701 / \propto V$ & شركت بهرهبردارى ميراب زايندهرود \\
\hline v & $\Lambda \uparrow / v G$ & 1 & $|\Psi| / V G$ & v & $7 \pi V / r T$ & شوراى خبر كان كشاورزى (خانهُكشاورز) \\
\hline 7 & $\Lambda \Delta / T \Delta$ & r & IrN/VG & $\wedge$ & $0 \times q / 10$ & نظام صنفى كثاورزى \\
\hline
\end{tabular}

معنى دارى بين نظرات دو گروه ذينفـع و ذئمـدخل وجــود دارد.

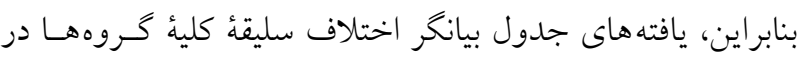

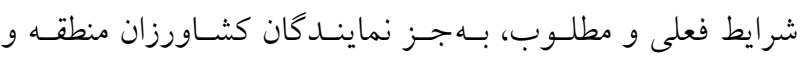
بخش صنايع و معادن در شرايط مطلوب مى بـاشد. جهت بررسى راههاى حل تعارض در اين مطالعه، در بخش نخست، روشهاى رايج حل بحران در شـرايط فعلى و سـسـ روش هاى حل تعارض در شرايط مطلوب مـورد ارزيـابى قـرار

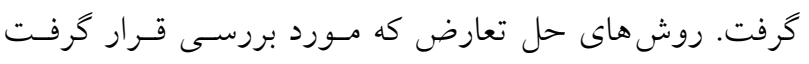

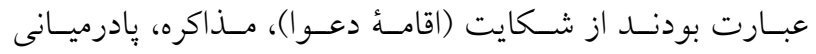
(ميانجيكرى)، داورى (حكميت)، توسل بـه زور، تسهيلكرى و
برحسب نتايج آزمون، مشاهده مسى شـود كـه نظـر ذىنفعـان در

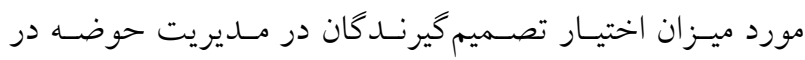
شر ايط فعلى و مطلوب يكسان نمىباشد. همجنِنين، ذى مـدخلان ميزان اختيارات آب منطقهاى، بخش صنايع و معادن و شهردارى را در شرايط فعلى و مطلوب يكسان نمىدانند.

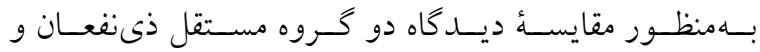
ذىمدخلان در مورد تصميم كيرندكان در شرايط فعلى و مطلـوب،

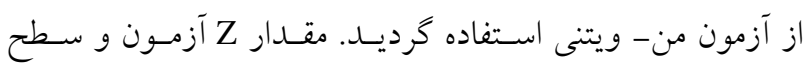
معنى دارى در جدول (11) ارئه كرديده است. از آنجايى كه سطح معنى دارى كوجّكتر از هـ/ است به احتمال ه9 درصـد تفـاوت 
جدول ه ا. نتايج آزمون ويلكاكسون براى مقايسهُ ديدكاه اعضاى جامعه آمارى در مورد تصميم گيرندگان در شرايط فعلى و مطلوب

\begin{tabular}{|c|c|c|c|c|}
\hline \multicolumn{2}{|c|}{ ذىنفعان } & \multicolumn{2}{|c|}{ ذىمدخلان } & \multirow{2}{*}{ بخشهاى تصميم گيرنده } \\
\hline سطح معنى دارى & 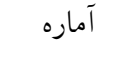 & سطح معنى دارى & آماره & \\
\hline$\circ / \circ \circ \circ$ & $-Q / \circ \wedge \uparrow$ & $0 /$ TYV & $-1 / 10 \Lambda$ & آب منطقهاى \\
\hline$\circ / 0 \circ 0$ & $-9 / 79 V$ & $\circ / 0 \circ 0$ & $-r / 90 \circ$ & جهاد كشاورزى \\
\hline$\circ \% \circ \circ$ & $-10 / 0 V Y$ & $\circ / 0 \circ 0$ & $-y / 4 r y$ & نمايند گان كشاورزان منطقه \\
\hline$\circ / 0 \circ \circ$ & $-Y / r \wedge r$ & $\circ / \backslash \Lambda \backslash$ & $-1 / \mu T V$ & بخش صنايع و معادن \\
\hline$\circ / 0 \circ 0$ & $-9 / 4 \Delta \varphi$ & ०/DTr & $-0 / 9 \mathrm{YO}$ & شهردارى \\
\hline$\circ / 0 \circ 0$ & $-Y / N \mu q$ & $\circ / \circ \circ 4$ & $-Y / 91 V$ & شركت بهرهبردارى ميراب زايندهرود \\
\hline$\circ \% \circ 0$ & $-G / 4 \wedge \mid$ & $\circ / 0 \circ 0$ & $-Q / \Gamma \circ \circ$ & شوراى خبر كان كشاورزى (خانهُ كشاورز) \\
\hline$\circ / 0 \circ \circ$ & $-G / Y \wedge V$ & $\circ / 0 \circ 0$ & $-\psi / 9 \mu \wedge$ & نظام صنفى كشاورزى \\
\hline
\end{tabular}

جدول الا. نتايج آزمون من- ويتنى براى مقايسهُ ديدگاه جامعة آمارى درمورد تصميم گيرندگان درشرايط فعلى و مطلوب

\begin{tabular}{|c|c|c|c|c|}
\hline \multicolumn{2}{|c|}{ شرايط مطلوب } & \multicolumn{2}{|c|}{ شرايط فعلى } & \multirow{2}{*}{ بخشهاى تصميم گيرنده } \\
\hline سطح معنى دارى & آماره & سطح معنىدارى & آماره & \\
\hline$\circ / 0 \circ 0$ & $-D / 4 Y G$ & O००Y & 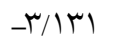 & آب منطقهاى \\
\hline$\circ / 0 \circ \circ$ & $-9 / 199$ & $\circ \circ \circ \circ$ & $-Y / T \Delta V$ & 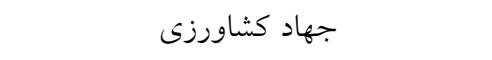 \\
\hline $0 / 9 Y \wedge$ & $-\circ / \uparrow \wedge \Delta$ & $\circ / \circ \circ \circ$ & $-Q / \mu \Gamma \wedge$ & نمايند گان كشاورزان منطقه \\
\hline$\circ / 10 \wedge$ & $-1 / 4 \mid T$ & $0 / 001$ & $-r / 4 \circ 1$ & بخش صنايع و معادن \\
\hline$\circ / \circ \circ Y$ & $-r / I F V$ & $\circ \circ \circ \circ$ & $-V /$ KYY & شهردارى \\
\hline$\circ / 0 \circ \circ$ & $-9 / 094$ & $\circ \% \circ \circ$ & $-V / 4 \vee V I$ & شركت بهرهبردارى ميراب زايندهرود \\
\hline$\circ / 0 \circ \circ$ & $-9 / \Lambda \Lambda \circ$ & $\circ / 0 \circ \circ$ & $-9 / Y \wedge 1$ & شوراى خبر گان كشاورزى (خانهُ كشاورز) \\
\hline$\circ / 0 \circ 0$ & $-9 / 401$ & $\circ / 0 \circ \circ$ & $-\Lambda / Y \Delta \Delta$ & نظام صنفى كشاورزى \\
\hline
\end{tabular}

داورى (حكميت) نيز كمكـاربردترين روشهـاى حـل تعـارض مىباشند. نكتهُ جالب ايناست كه ذىنفعان (كشاورزان) توسل به زور، تسهيلكرى و اقامٔ دعوا را رايجتـــين روشهــا در شــرايط فعلى دانستهاند (جدول با ). درحالى كه ذىمدخلان از مـذاكره، ميانجيخرى و داورى بهعنوان رايجترين روش ها نام بردهانـد. در

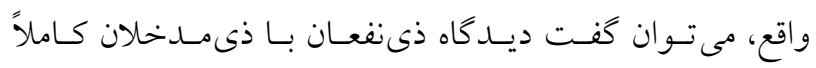

$$
\text { مغايرت دارد. }
$$

در مورد راههاى حل تعارض در شرايط بهينه نيز نتايج نشان مى دهد كه از نظر نمونهُ آمارى يـزّوهش، ايجـاد شـرايط بـاز كو كردن نظرات بهصورت آزادانه، يادرميانى (ميانجيخرى) و مذاكره
ايجاد شرايط باز گو كردن نظرات بهصورت آزادانه.

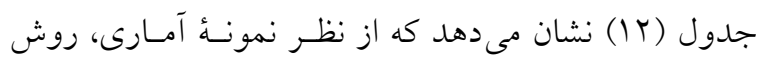
توسل به زور رايجترين روش در بين ساير روشهاست. حسدود 0/00 درصد با انتخاب متوسط، زياد و خيلى زياد، ايسن روش را رايج دانستهاند و نيز //91 درصد با انتخاب هـيج، خيلى كـم و كم، روش يادرميانى يا ميانجيخرى راكـم كـاربردترين روش در بين ساير روشها معرفى نمودهاند.

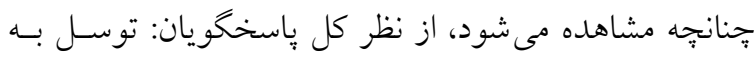
زور، شكايت (اقامهٔ دعوا) و تسـهيلحرى رايـجتـرين روشهـاى حل تعارض در شرايط فعلى هستند. يُادرميانى (ميـانجيخرى) و 
جدول أ. ديدگاه ياسخگويان در مورد رايجترين روشهاى حل تعارض در شرايط فعلى

\begin{tabular}{|c|c|c|c|c|c|c|c|c|c|c|c|c|}
\hline \multicolumn{2}{|c|}{ خيلىزياد } & \multicolumn{2}{|c|}{ زياد } & \multicolumn{2}{|c|}{ متوسط } & \multicolumn{2}{|c|}{ كم } & \multicolumn{2}{|c|}{ خيلى كم } & \multicolumn{2}{|c|}{ هيج } & \multirow{2}{*}{ ن ام متغير } \\
\hline$\hat{\jmath}$ & $\frac{\frac{2}{2}}{\frac{3}{3}}$ & $\hat{\jmath}$ & $\frac{\frac{9}{2}}{3}$ & $\hat{\hat{\jmath}}$ & $\frac{2}{\frac{2}{3}}$ & $\hat{\jmath}$ & $\frac{\frac{2}{2}}{\frac{9}{y}}$ & $\hat{\jmath}$ & $\frac{\frac{2}{2}}{\frac{9}{y}}$ & $\hat{\jmath}$ & $\frac{\frac{2}{2}}{\frac{9}{3}}$ & \\
\hline $\mathrm{V} / \mathrm{V}$ & 19 & $9 / 1$ & 19 & re & or & $1 / 9$ & r & $\Lambda / V$ & 11 & $49 / 9$ & $9 V$ & شكايت (اقامٔٔ دعوا) \\
\hline $1 / 9$ & r & $r / 4$ & $\Delta$ & $11 / 1$ & ro & 9 & 19 & $\Lambda / \Delta$ & 11 & $99 / 0$ & $|4|$ & مذاكره \\
\hline $1 / 4$ & $\mu$ & $r / \mathcal{C}$ & $\Delta$ & $\Delta / 1$ & 11 & 9 & 19 & 9 & 19 & $V \mu / 1$ & 100 & يادرميانى (ميانجيخرى) \\
\hline $1 / 4$ & r & $1 / 9$ & r & $9 / 4$ & ro & $V / 0$ & 19 & $Q / Y$ & 11 & $V \Psi / Q$ & 101 & داورى (حكميت) \\
\hline$r / 4$ & 0 & $r Q / q$ & $\Delta \Delta$ & $T Y / Y$ & $q v$ & $\mathrm{~V} / \mathrm{Q}$ & 19 & $\Delta / V$ & ir & $r q / r$ & VV & توسل به زور \\
\hline $1 / 9$ & r & $r / \Lambda$ & $\wedge$ & $V / \mathrm{l}$ & 10 & ry & VY & $\Lambda / \Delta$ & 11 & $k \psi / \Lambda$ & 90 & ايجاد شر ايط باز گوى \\
\hline $\mathrm{r} / \mathrm{\Lambda}$ & $\wedge$ & $r / \mathcal{T}$ & 0 & $r / r$ & 9 & $11 / 1$ & $r Q$ & $r Y / D$ & Or & $\Delta r / \mu$ & 111 & كردن نظرات به صورت \\
\hline
\end{tabular}

جدولسا. اولويتبندى روشهاى رايج حل تعارض در شرايط فعلى

\begin{tabular}{|c|c|c|c|c|c|c|}
\hline \multicolumn{2}{|c|}{ ذئنعان } & \multicolumn{2}{|c|}{ ذيىمدلان } & \multicolumn{2}{|c|}{ كل ياسخخويان } & \multirow[b]{2}{*}{ عوامل } \\
\hline اولويت & ميانكين & اولويت & ميانخين رتبه & اولويت & ميانخين رتبه & \\
\hline 1 & 110 & V & $\Lambda G / V^{C}$ & 1 & $1019 / 47$ & توسل به زور \\
\hline r & $9 \circ / 49$ & 7 & ITr/NT & r & $991 / 97$ & شكايت (اقامهُ دعو ا) \\
\hline r & $9 T / 4 \wedge$ & $\Delta$ & $149 / 11$ & r & $\wedge \vee \Delta / 11$ & تسهيلخرى \\
\hline$r$ & $M N / Y_{0}$ & r & $\mid K K / N K$ & r & $\vee \wedge Q / Q \Lambda$ & ايجاد شرايط بازكو كردن نظرات \\
\hline v & $\Lambda T / Y)$ & 1 & $10 V / 94$ & 0 & VYV/VY & مذاكره \\
\hline$\Delta$ & $\Lambda N / T q$ & r & IFY/AG & 4 & רזr/רq & داورى (حكميت) \\
\hline 7 & $\Lambda V / V Q$ & r & $|Y \varphi / T|$ & v & TVN/IV & يادرميانى (ميانجى گرى) \\
\hline
\end{tabular}

مى توانند مؤثرترين روش هاى حل تعارض باشند (جــدول \& (1). شده است.

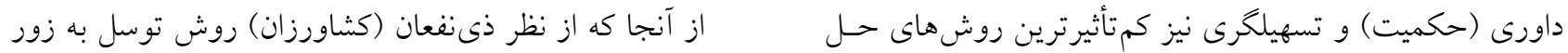

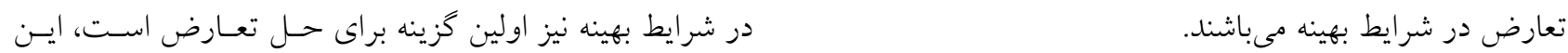

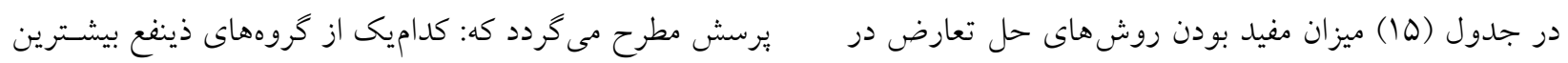

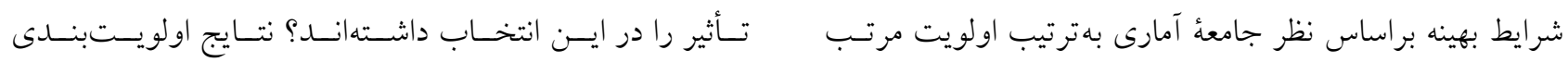


جدول أl. ديدگاه يّاسخگويان در مورد مؤثرترين روشهاى حل تعارض در شرايط بهينه

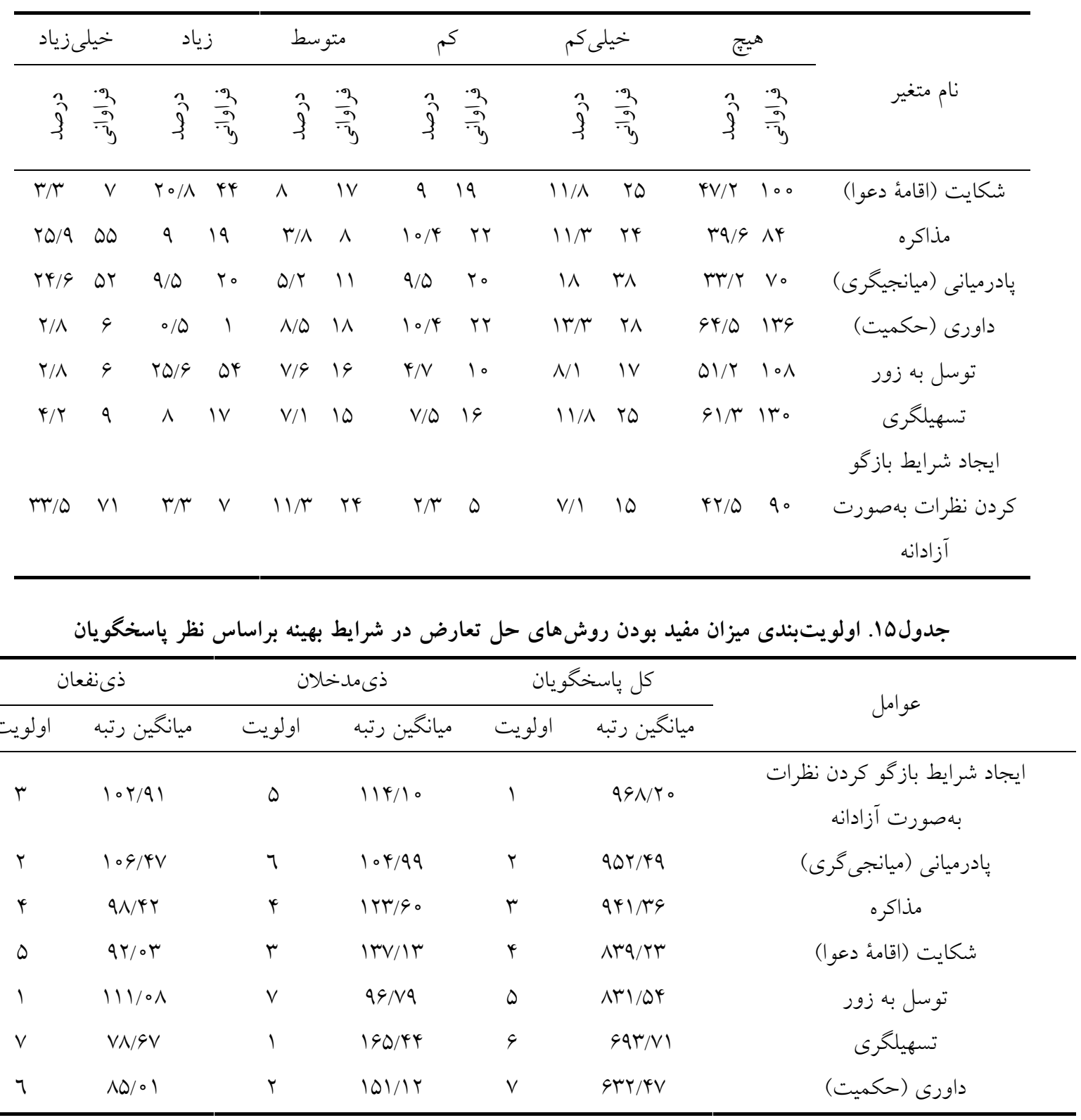

جدول 19. اولويتبندى انتخاب روش توسل به زور در شرايط بهينه براساس نظر كشاورزان

\begin{tabular}{|c|c|c|c|c|}
\hline 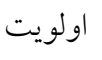 & ميانخين رتبه & 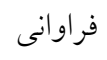 & ذى ذنفعان (كشاورزان) & رديف \\
\hline r & $10 \wedge / 0 \circ$ & 11 & روستاهاى استان جهارمحال و بختيارى & 1 \\
\hline 0 & $94 / 91$ & rA & روستاهاى بالادست استان اصفهان (كانالهاى سنتى) & r \\
\hline 4 & $\Delta \& / V I$ & r & روستاهاى شبكةُ نكو آباد & r \\
\hline i & $90 / 4 \wedge$ & rᄉ & روستاهاى شبكة آبشار و برخوار & r \\
\hline r & $\| V / r \Lambda$ & rq & روستاهاى شبكئ مهيار & 0 \\
\hline \multirow[t]{2}{*}{1} & $119 / 4 r$ & r。 & روستاهاى شبكهُ رودشتين & 4 \\
\hline & & $\mid \mathrm{VI}$ & جم- & \\
\hline
\end{tabular}


جدول IV إ. مقايسهُ نظرات جامعهُ آمارى با استفاده از آزمون من ويتنى

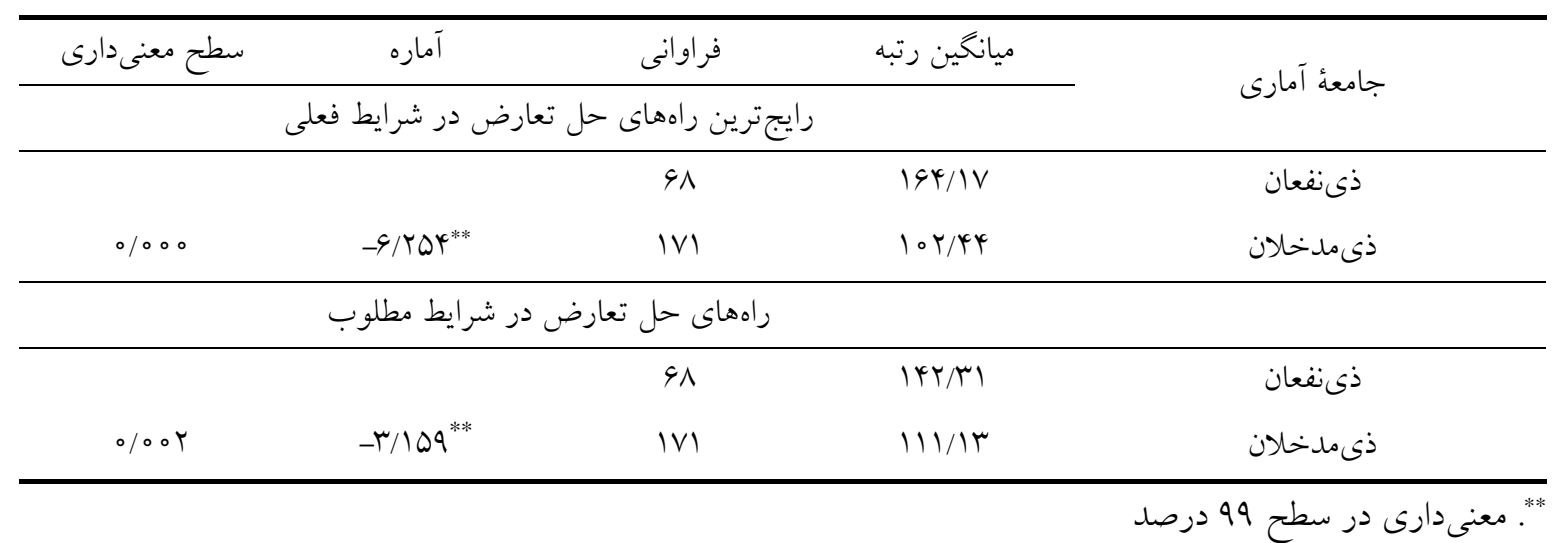

براى حل تعارضات بالقوه و جارى وجود ندارد، استفاده از تجـارب ساير كشورها در زمينهُ كاربرد شيوههاى مـؤثر حـل تعـارض، بــراى رسيدن به توافقات آبى در كشور مفيــ خواهـــ بـود. از آن جملـه، تجربيات هند و ايالات متحده كه دو كثور فدرالى با مناطق متمـايز

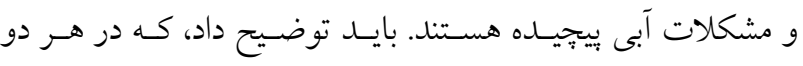
كشور اختلافات آبى جدى ميان ايالتها وجـود دارد كـه بعضى از آنها سالهاى زيادى است، ادامه دارند. تجربهُ موفـق ايـن دو كشـور در زمينه اتخاذ سـازوكارهاى مناسـب حـل و فصـل اختلافـات در رودخانههاى مشترك بهويسرّه در دورههــاى كمبـود آب نشـان از آن دارد، به لحاظ آنكه اقامهٔ دعوا در جهت تقسـيم عادلانـهُ منــابع بـين ذى نفعان راهكارى بسـيار زمـانبـر، برهزينـهـ و همجنــين غيرقابـل بيشبينى است، لذا، در هر دو كشور مذاكرات دو يا تجند جانبه بـين ايالتها، راهكارى است كه ترجيح داده مىشود (ه (1). كفتنى اسـت كه اين راهكار در اين بررسى نيز بهعنوان مناسبترين شيوهُ حل تعارض، از سوى ذىمدخلان مطرح شده است.

\section{نتيجه كيرى}

كشور ما در يك اقليم خشك و نيمه خشك واقـع شـده كـه آب نقش كليدى در توسعهُ آن دارد. با توجـهـ بـهـ ازديـاد جمعيـت و

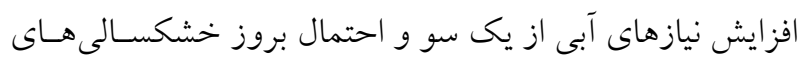

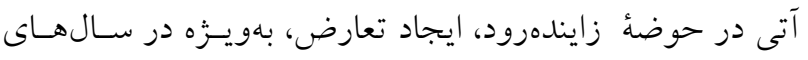
كمآبى بيش رو، طبيعى است و بايد آن را انتظار داشت. مطالعات نشان مى دهد كه: افزايش جمعيت، استفاده از شيوههاى سـنتى و
كروههاى ذينفع، از نظر انتخاب روش توسل به زور در شـرايط بهينه در جدول (9) نشان مى دهـد كـه: بـهـترتيـب روسـتاهاى شبكة رودشتين، روسـتاهاى شـبكة مهيـار و روسـتاهاى اسـتان جهار محال و بختيارى موافقترين كروههــا بـا روش توسـل بــه

زور بودهاند.

بهمنظور مقايسهُ نظرات گـروههــاى ذينفـع و ذى ذمــخل در مورد رايجترين راههاى حل تعارض در شـرايط كنـونى و بهينـه، بهدليل وجود دو گروه مستقل، از آزمون من - ويتنى استفاده شد. نتايج آزمون در جدول (IV) ارائه شده است. با توجه به نتايج بهدست آمده، تفاوت معنسى دارى در سـطح

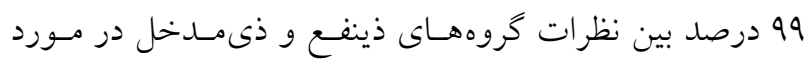
رايجترين راههاى حسل تعـارض در شـرايط فعلى وجـود دارد. بنابراين، نظرات گروههاى ذينفع و ذىمدخل در مورد رايجترين

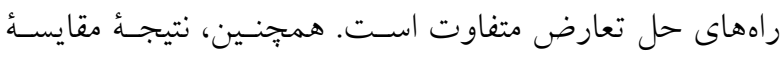
ميانخينها نشان داد كه تفاوت معنسى دارى در سـطح 99 درصــ بين ديد گاه گروههـاى ذينفـع و ذى مـدخل در مـورد مـؤثرترين راههاى حل تعارض وجـود دارد. بنـابراين، نظـرات گـروههـاى ذينفع و ذىمدخل در مورد مؤثرترين راههاى حل تعارض مانند

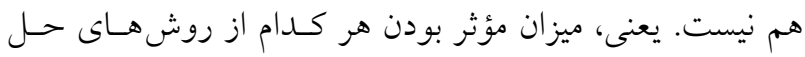

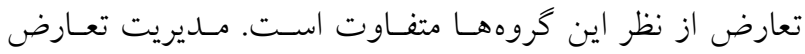
ايجاب مى كند كه منشأ اين تفاوتهــا بررسى شــــ تـا طـرفين در جهت حل تعارض به توافق برسند.

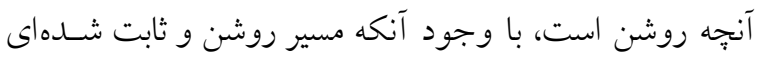


خوش بينانهتر است؛ اما بهنظر مىرسد دجّار يك ضعف اساسى است و آن اينكه ذىمدخلان تصوير كاملى از وضسعيت موجـود

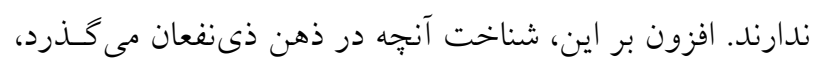

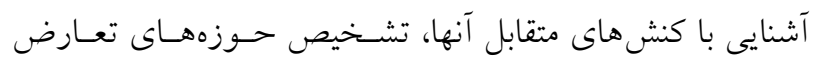
برانخيز و نحوهُ برخورد با عقايد مخالف، در هدايت واكنشهاى كشاورزان بهسمت انتخاب راهحل هاى مسالمت آميز مؤثر است. لازم بهذكر است كه شيؤ توسـل بـه زور در ادارة تعـارض،

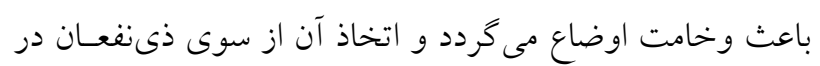

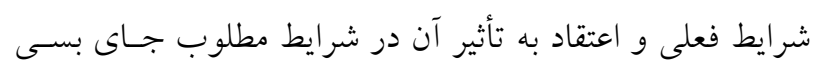

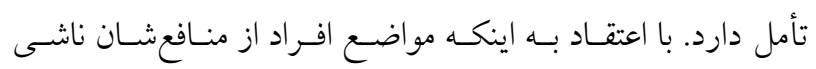

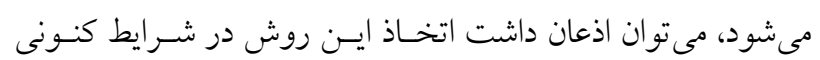
توسط كشاورزان بيانگر آن است كه ذىنفعان بيشـتر روشهـايى را برمى گزيند كه سريعتر به نتيجه برسد و شايد دليل ايسن امـر را بايــد

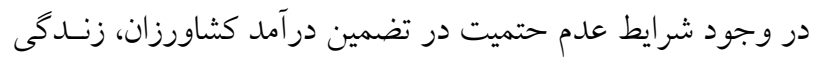
معيشتى وابسته به فعاليتهاى كشاورزى و نبود شغل جـايكزين در زمان بروز خشكسالىهاى فصلى جستجو كرد. اين مطالعه نشان مى دهد كه: دانستهها و نادانستههـاى مسئولين از رفتار ذىنفعان به جهه ميزان است. جِنين شناختى همـان محتـواى

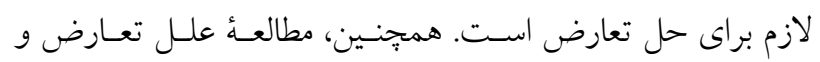
راههـاى حـل تعـارض امكـان موفقيـت بيشـترى را بــراى كـاربرد مناسبتـرين روشهــاى حـل تعـارض، در راسـتاى اداره تعـارض فراهم مىنمايد.
كم بازده آبيارى و برنامهريزىهـاى بسىرويـهـ در توسعـة بخـش

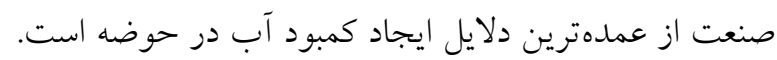

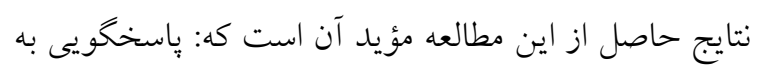
نيازهاى درحال رشد، عدم جامعنخرى در اقدامات انجام شـده و نيز بى توجهى به عواقب تصميمات اتخاذ شده بر رونـــ زنـدكى

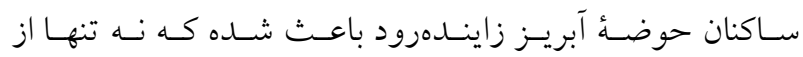
سرمايه كذارىهاى انجام شده بهصورت كارا استفاده نشود، بلكه نتيجة اين اقـامات موجبـات نارضـايتى در يـائين دسـت و بـا كذشت زمان، ايجاد تعارض در اين منطقه را فراهم نموده است. بهطورى كه در اين مطالعه عنوان شد، فراخيـر بـودن تعـارض، ايجاب مى كند كه تعارض مديريت شود و بـهـ توافـق بيانجامــ. در ادارهُ تعـارض، قبـل از ارائسهُ راههــاى حـل تعـارض، مـــيريت تعارض اهميت دارد. جرا كه مديريت تعارض با شناسايى علـل

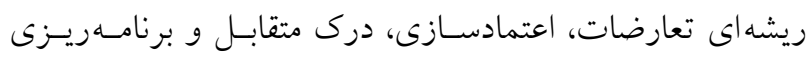
مشاركتى براى انجام وظايف بيّجيده، نقش مؤثرى در جلو گيرى

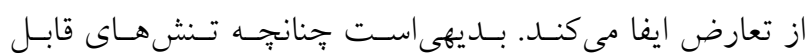
مذاكره مديريت شوند، هر گز به تعارضات غيرقابل مذاكره تبديل

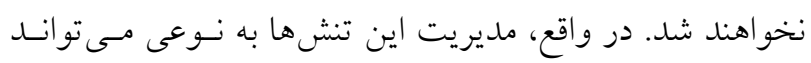
سرعت حل اختلافات را تسريع كند. همجنين، نتايج اين يزوهش كوياى وجـود تفـاوت اساسى ميان ديدگاههاى ذى نفعان و ذىمدخلان است، كه بسيار نخـــران كننده است. گرجهه راهحل هاى ارائه شـده از سـوى ذئمـدخلان

\section{منابع مورد استفاده}

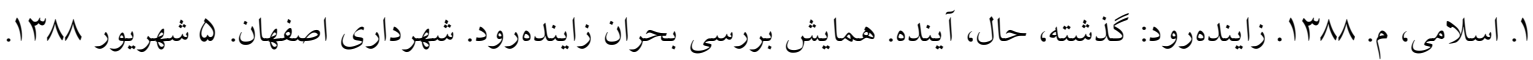

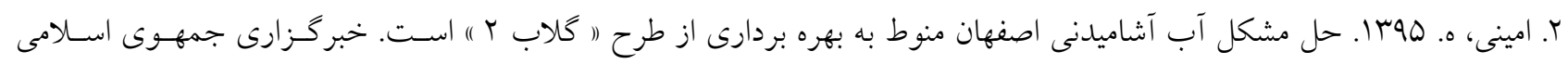

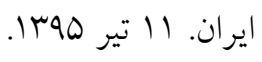

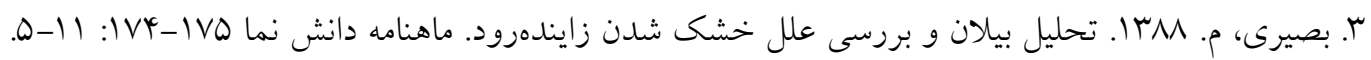

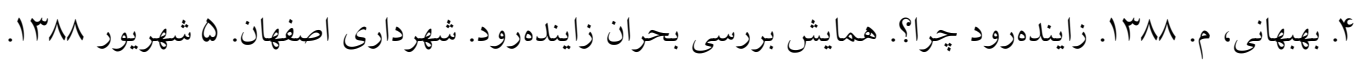

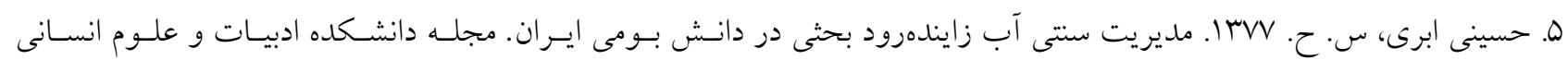

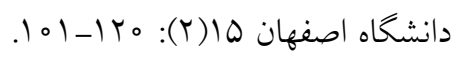

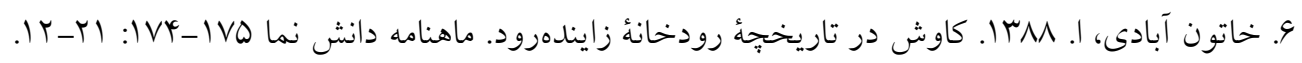




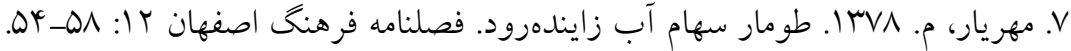

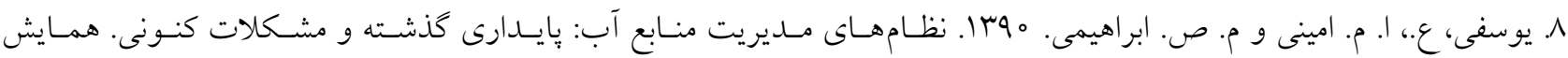

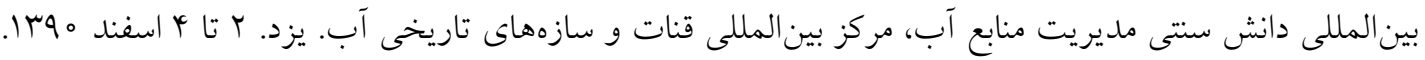

9. Burton, J. 1990. Conflict: resolution and prevention. St. Martin's Press. PP. 295. New York.

10. Cap-Net. 2005. Conflict resolution and negotiation skills for integrated water resources management. PP. 97. United Nations Development Programme. Available at: http://www.cap-net.org/download-document/?doc=3642\&id=CR\%20Training\%20Manual.

11. Moore, C. W. 2014. The mediation process: practical strategies for resolving conflict. John Wiley \& Sons, PP. 704. San Francisco.

12. Mostert, E. 2003. Conflict and cooperation in the management of international freshwater resources: a global review. UNESCO-IHP. Available at: www.unesco.org/water/wwap/pccp.

13. NOSR. 2007. Conflict and security. Netherlands Organisation for Scientific Research, The Hague, Netherlands.

14. Schmid, A. P. and S. B. Anderlini. 2000. Thesaurus and glossary of early warning and conflict prevention terms. Forum on Early Warning and Early Response (FEWER). PP. 145. London.

15. Seligman, D. 2011. Resolving interstate water conflicts: a comparison of the way India and the United States address disputes on interstate rivers. Serial No.IWP/WP/No.2/2011. National University of Singapore.

16. Svendsen, M. 2004. Irrigation and river basin management: options for governance and institutions. CABI Publishing. PP. 259. UK.

17. UNESCO. 2006. Water: a shared responsibility (Vol. 2). World Water Assessment Programme. UNWATER/WWAP/2006/3. Berghan Books .

18. Warner, M. 2000. Conflict management in community-based natural resource projects: experiences from Fiji and Papua New Guinea. Overseas Development Institute, No. 135, London. UK.

19. Warner, M. 2001. Complex problems, negotiated solutions: tools to reduce conflict in community development. ITDG Publishing. PP. 149. London. UK. 


\title{
Farmers' and Authorities' Attitudes towards the Water Conflict Resolution Methods in Zayandeh-Rud River
}

\author{
A. Yousefi ${ }^{*}$ A. M. Amini, O. Fathi and A. yadegari ${ }^{1}$
}

(Received: Jan. 06-2015; Accepted: March 07-2016)

\begin{abstract}
Water, as a limiting factor, has played a decisive role in shaping and development of Iranian culture and civilization. Water scarcity and a great variety of water users lead to conflicts in rivers' environment. Conflict resolution is conceptualized by the methods and processes involved in peaceful facilitating and ending of the conflict through active communication about their thinking and causes of disagreement as well as persistence in collective negotiations. Currently, the Zayandeh-Rud River basin (ZRR) has been facing severe water scarcity. The aim of this study is to evaluate the methods of water conflict resolution in the ZRR from the viewpoint of farmers and authorities. The statistical population of this study includes all farmers in ZRR and selected staff of Regional Water Authority and Agricultural Organization (Jahad-Keshavarzi) in both Isfahan and Chaharmahal \& Bakhtiyari provinces. Data were collected through a sample of 171 farmers and census of authorities through face-to-face interviews based on a comprehensive structured questionnaire. Before the survey, the reliability and validity of the questionnaire was initially evaluated on a pre-test study respectively by using Cronbach's alpha coefficient and Kaiser-Meyer-Olkin (KMO) criteria. The results showed that the main factors in creating the conflict are drought, increased water use in industry and increased water consumption in other provinces. Furthermore, the most suitable methods of water conflict resolution are the conditions where everybody is able to speak freely, mediation and negotiation. On one hand, in the current situation, farmers prefer violent manners and on the other hand, authorities consider negotiation as the most appropriate solution to the conflict.
\end{abstract}

Keywords: Conflict resolution, Mediation, Negotiation, Violent manner, Zayandeh-Rud River.

1. Dept. of Rural Development, Faculty of Agric., Isfahan Univ. of Technol., Isfahan, Iran.

*: Corresponding Author, Email: ayousefi@cc.iut.ac.ir 